\title{
Understanding External and Cascading Benefits for HIV/AIDS Control in a Subsistence Marketplace: Insights from Indonesia
}

\author{
Denni Arli and Jack Cadeaux
}

\begin{abstract}
The objectives of this study are (1) to examine user perceptions and preferences toward various HIV/AIDS prevention control products and services and (2) to explore how both perceived likelihood of infection and beliefs about external benefits might distinctively affect intentions to use various HIVIAIDS-prevention goods and services in poor communities. The study compares a sample drawn from a subsistence marketplace (a redlight district in a major city) with one drawn from a relatively non-subsistence marketplace (a university area in the same city) in Indonesia. In spite of significant differences in education, income, and sexual activity, the two samples show a surprising degree of similarity in generic positioning maps for the six HIVIAIDS-prevention goods and services. Quite concerning, though, is the finding that in the higher-risk, subsistence setting, individuals actually infected with HIV are less likely to use HIV/AIDS-prevention goods and services than are those who are not infected. The authors review these empirical results in light of (1) theories of external, cascading benefits, and generalized exchange and (2) a theory of subsistence marketplaces in developing economies.
\end{abstract}

Keywords: external benefits, cascading benefits, subsistence marketplace, HIV/AIDS, Indonesia

G lobally, over 1.7 million people died of AIDS-related illness in 2012, more than any other infectious disease (World Health Organization 2013). HIV/AIDS has had a devastating effect throughout the world, especially for people living in bottom-of-pyramid or subsistence markets. People living in such markets often have relatively limited access to health care and to educational and marketplace opportunities to exit poverty (Gau et al. 2014; Viswanathan et al. 2009). Subsistence marketplaces contain $95 \%$ of all people who have HIV (Chance and Deshpandé 2009). Asia-Pacific countries face a risk of increased incidence of HIV/AIDS because several billion people in these countries are in the most sexually active age group (i.e., 15-49 years) (World Health Organization 2001). Governments and other organizations have focused on both community initiatives and social marketing efforts to inform those infected with HIV/AIDS and to spread awareness about prevention mechanisms, particularly in developing countries (UNAIDS 2010). Apart from conventional social marketing communication efforts to change attitudes and behavior, prevention efforts can also entail substantive exchanges of goods and services. Many of these exchanges involve the consumption of goods and services that can have positive social or external benefits. The key problem this study addresses is

Denni Arli is Senior Lecturer in Marketing, Griffith Business School, Griffith University (e-mail: d.arli@griffith.edu.au). Jack Cadeaux is Associate Professor of Marketing, University of New South Wales (e-mail: j.cadeaux@unsw.edu.au). Jerome Williams served as associate editor for this article. how potential users' and beneficiaries' perceptions and beliefs about such external benefits affect their willingness to use products and services that might prevent HIV/AIDS.

In principle, external benefits are benefits that are not included in the user's valuation of a product or its use. Such benefits are essentially free to the beneficiary in the form of an advantage of production or consumption conferred without charge to a third party not directly involved in the relevant economic transaction or activity (Cadeaux 2000; Cornes and Sandler 1986; Nason 1989; Rosen 1988). For example, individuals who consume vaccines reduce the risk to others of contracting the disease that the vaccine aims to prevent. While vaccines produce obvious benefits for users, at sufficiently high levels of vaccination in a population, others (whether vaccinated or not) receive significant health and welfare benefits because the vaccinated people around them are less likely to carry the infection. However, individual demand for vaccines depends broadly on prevalence of the target disease and, in local markets, on the number of people the individual may come into contact with who carry the disease (Sloan 2012). If too few are infected or, alternatively, a threshold of immunity is reached, then individual incentives to vaccinate can disappear, leaving only pure external benefits. Other, less well-known consumption practices can also have external health benefits. A practice common in Indonesia that produces a real positive external benefit is male circumcision. In Indonesia, most men, especially Muslims, are circumcised. This factor might have had the unintended consequence of helping limit the speed of HIV infection among sex workers (Elmendorf, Jensen, and Pisani 2005).

Although some researchers have offered theories about how beliefs related to external benefits, and their heterogeneity in a 
population, could affect the viability of policy mechanisms to address the related market failures, little or no empirical evidence is available to support or refute such theory. For example, Cadeaux (2000) argues that heterogeneity in beliefs and perceptions related to goods and services with potential external benefits could quite broadly lead to misperceptions of market failure and even potential regulatory failure associated with mandatory consumption and subsidy schemes for goods and services claimed to offer such benefits, such as, for example, HIV testing kits. However, that study offers no empirical evidence concerning that claim. With the current study, we hope to address this gap in part.

This study examines the potential for such heterogeneity by comparing a subsistence marketplace (in this case, a red-light district in a large Indonesian city), which contains a relatively high-risk population of sex workers and their clients, with a non-subsistence marketplace (in this case, a university setting), which represents a more developed subpopulation in Indonesia that is at lower risk of infection. Although ethnically similar, these two marketplaces have significantly different profiles in terms of religious status and subculture (specifically, in terms of educational levels and sexual lifestyles). The specific empirical objectives of the study are as follows: (1) to examine user perceptions and preferences toward various products and services for HIV/AIDS prevention and control and (2) to explore how both perceived likelihood of infection and beliefs about external benefits might distinctively affect intentions to use various HIV/AIDS-prevention goods and services in poor communities in developing countries that lie outside the formal market economy. To develop effective policies for HIV/ AIDS prevention and epidemiological control in Indonesia and in countries with similar political, religious, and demographic profiles, it is important to understand the factors that affect the use of a range of products and services that could prevent or control such an epidemic.

\section{Literature Review and Hypothesis Development}

The literature overview first briefly reviews the concept of external benefits of consumption and how generalized exchange mechanisms can offer a potential mechanism for their management. We then discuss how the sex worker community in Indonesia might constitute a subsistence marketplace in which a high level of network embeddedness prevails. By invoking a theory of cascading benefits, this section argues that, perhaps ironically, in such a marketplace, generalized exchange mechanisms might explain what otherwise would appear to be purely altruistic behaviors. This section concludes by developing a set of empirical hypothesis to test these broad predictions in the context of a field survey in Indonesia.

\section{External Benefits of Consumption}

An external (or social or spillover) benefit of consumption is a benefit to nonusers that arises from the use of a product or services (Buchanan and Faith 1981; Cadeaux 1995, 2000; Rosen 1988). Such benefits are often not part of a user's valuation of a good, or they may otherwise arise as benefits that are free to the beneficiary in the form of an advantage of production or consumption conferred without charge to a third party not directly involved in the relevant economic transaction or activity (Cornes and Sandler 1986; Nason 1989; Rosen 1988). For example, vaccinated individuals reduce the risk of contracting the relevant disease for all others around them.

Rather than focusing on such real social benefits as externalities, many studies in marketing and economics have focused on network externalities. Network externalities arise when a large customer network increases individual consumer utility, either directly as a function of the number of users (and perhaps their network structure), or indirectly as a function of the development of complements (Shankar and Bayus 2003). Examples include ATMs (Hannan and McDowell 1984; Saloner and Shepard 1995), electronic bill payment systems (Au and Kaufmann 2001), information systems (Chismar and Meier 1992), spreadsheet software packages (Gandal 1994), and mobile phones (Wang, Lo, and Fang 2008). This widely examined phenomenon that arises with many technological and information goods lies outside the scope of this study. Its process for utility generation is quite different from that by which goods or services such as vaccination or HIV/AIDS education generate third-party health benefits. Furthermore, market failures usually do not arise for such network externalities. Policy implications for network externalities usually entail strategies for competitive entry, complementary entry, and incumbency protection. In contrast, because of the potential for market failure (Arrow 1963; Demsetz 1964), policy implications for goods and services with epidemiological control benefits (e.g. condoms, vaccines, HIV/AIDS education) usually entail public policies such as direct or indirect consumption subsidies or the support and encouragement of intermediaries such as nongovernmental organizations (NGOs) rather than policies for marketing and competitive strategy. For example, following Carman's (1980) discussion of generalized exchange in marketing, Cadeaux (2000) proposes but does not test a theory about how generalized exchange mechanisms involving third-party intermediaries such as NGOs might help address the market failures associated with such consumption externalities.

In addition to problems of market failure, many goods and services that could control HIV/AIDS involve significant usage barriers or usage costs even if they are subsidized or free. For example, in the case of Indonesia, even though condoms are highly effective in preventing HIV infection, they entail usage costs such as time spent in procurement and application, inconvenience, embarrassment, and, for some people, reduced pleasure (Ainsworth 1998). Furthermore, many individuals involved in unsafe sex practices are likely to make decisions according to their own perceptions of risk of being infected by HIV, while ignoring the risk they might impose on others. Thus, despite knowing the risk of unsafe sexual behavior, people still persist in risky behavior because although the costs of safer sex behavior are clear and direct, its external benefits are uncertain and distant (Ainsworth 1998). In particular, evidence suggests that those who are infected and most likely to generate positive external benefits by practicing safer sex are not likely to make a socially favorable trade-off. For example, high rates of active syphilis among the HIV-positive indicate that those who are infected are still having unprotected sex with several partners (Elmendorf, Jensen, and Pisani 2005). HIV is easily transmitted from one high-risk group to another (Elmendorf, Jensen, and Pisani 2005). 
Such externalities affect the viability of policies for HIVprevention programs. Ainsworth (1998) suggests that due to the impact of externalities on behavior, public policy makers should support effective prevention programs among high-risk groups who are most likely to contract and spread HIV. Tables 1 and 2 outline various conceptual and empirical studies on externalities.

\section{Subsistence Marketplaces and Cascading Benefits}

Viswanathan, Rosa, and Ruth (2010, p. 535) define a subsistence marketplace as a "state of being resource-poor, barely having sufficient resources for a day-to-day living" but having "the possibility of richness in other dimensions, such as being network-rich through social relations." In the context of buyer-seller exchange among the marginalized, Viswanathan et al. (2012) find two themes that characterize how interactions play out in day-to-day commercial activities: interactional empathy, which focuses on the human dimension and the need and circumstances of each person; and enduring relationships, which focuses on the importance of cultivating long-term relationships between buyers and sellers. Viswanathan et al. (2012, p. 168) suggest that "empathy may be more common in subsistence environments in which marketplace actors are heavily invested in their common futures and simultaneously socially isolated from other formal marketing systems." Such marketplaces are often characterized by poverty, social inequality, scarcity of information, and low education (Layton 2007; Umashankar and Srinivasan 2013; Viswanathan et al. 2010).

One simple, obvious, but important characteristic of many subsistence marketplaces is their relatively high population density. Even in countries or regions with generally high densities (e.g., Indonesia and the island of Java in particular), members of subsistence marketplaces are often directly exposed to the full presence of their fellow community members and cannot easily escape to the relative seclusion of a large home, a gated community, or even a shopping mall. Sociologists have argued, however, that high population density can, in itself, offer a relatively high potential for generalized exchange
(Takahashi 2000). The reason for this is that in a high-density context, although an actor who behaves in a socially positive manner does not expect direct reciprocity by a direct beneficiary, the actor can reasonably expect that at some point he or she will be reciprocated by other actors in a dense community who receive benefits from the direct beneficiary (Levine and Kurzban 2006). Analysts refer to this process as an "evolutionary" theory of cascading benefits. In part, this study will examine how such a simple theory might predict and explain observed differences in the willingness to use goods and services beneficial for HIV/AIDs control.

Consumer beliefs about externalities of consumption could also arise because of differences in lay theories that sometimes, but not always, take into account processes that economic theory might predict. For example, experimental evidence in Western settings have suggested that preferences for government supply of services are highest when the service has few alternative suppliers and is important for health; however, in those experiments, perceived (negative) externalities have not been a significant predictor (Mahoney, Kemp, and Webley 2005). Regardless of either source of supply or supply market structure, the potential for goods and services to generate real positive externalities depends less on who supplies them than on the likelihood that consumers will use them. Thus, the hypotheses we posit subsequently address the potential for heterogeneity in perceptions associated with such potentially competing goods and services and in the way that beliefs about external benefits might predict use intentions. Thus, these hypotheses do not depend on any lay economic theory about the underlying production and market processes but instead try to capture the behavioral effects of beliefs, effects that are not visible to the social actors themselves and that do not depend on lay economic theory.

\section{Hypothesis Development}

This study frames its hypotheses in the empirical contexts of two contrasting settings in Surabaya, Indonesia. One of these is the sex worker community as found in a well-known red-light district in Surabaya. It may constitute a subsistence marketplace

Table 1. Relevant Research on Marketing and Externality (Conceptual Studies)

Conceptual Study Context

Daudigeos and Valiorgue (2011) Corporate social responsibility

Pastine and Pastine (2011)

Advertising

Biglan (2009)

Cadeaux (2000)
Companies that produce products with negative externalities

Residential security, auto theft deterrence, and HIV infection control
Main Findings

Negative externalities present firms with different strategic opportunities in terms of harnessing marketdriven demand for corporate social responsibility.

In markets with a consumption externality, advertising will have an effect; especially when the differences in the quality are not significant, consumers may often knowingly purchase the lower-quality product.

The article suggests that government should request that companies bear the cost of externality or costs that are currently imposed on others.

Third-party beneficiaries may hold diverse preferences for not only external benefits but also the alternative goods and services that create these benefits, which may suggest the viability of a matching process as a market mechanism. 
Table 2. Relevant Research on Marketing and Externality (Empirical Studies)

\begin{tabular}{|c|c|c|c|}
\hline Empirical Study & Context & Country & Main Findings \\
\hline Felzensztein, Huemer, and Gimmon (2009) & Fishery & Scotland, Chile & $\begin{array}{l}\text { Colocation in the salmon-farming industry may } \\
\text { produce several externalities, such as buying } \\
\text { immediate goods, enhanced reputation, and joint } \\
\text { participation in trade fairs. }\end{array}$ \\
\hline Brent (2009) & Health & Tanzania & $\begin{array}{l}\text { People were willing to pay different prices for the } \\
\text { condoms because the perceived quality varied. The } \\
\text { condom social marketing was considered socially } \\
\text { worthwhile when external benefits were included. }\end{array}$ \\
\hline Gonzales-Navarro (2008) & Technology & Mexico & $\begin{array}{l}\text { In Mexico, Lojack (i.e., a tracking technology for } \\
\text { stolen vehicles) generates negative externalities if } \\
\text { thieves can distinguish between Lojack-equipped and } \\
\text { non-Lojack-equipped cars. In addition, there is also an } \\
\text { increase of thefts in non-Lojack-serviced states. }\end{array}$ \\
\hline
\end{tabular}

Ayres and Levitt (1998) Technology United States

The introduction of Lojack produced large reductions in vehicle theft in areas in the United States where it was implemented.

due to its limited income and limited access to resources such as government health care services. Indonesian government policy toward female sex workers aims to rehabilitate and reintegrate them into the community (Andriansyah 2012; Jawa Pos 2014; Jones, Sulistyaningsih, and Hull 1995; Sedyaningsih-Mamahit and Gortmaker 1999). However, rehabilitation centers for sex workers operated by either national or provincial governments often have no well-planned program related to AIDS or sexually transmitted diseases (STDs) (Sedyaningsih-Mamahit and Gortmaker 1999; Terzis 2011). In addition, a sex worker in a religious nation such as Indonesia faces a complex situation. Sex workers are often categorized as lower-class or cast-off due to the nature of their job, which violates the norms of various religions in Indonesia. According to Schoepf (2001, p. 340), prostitutes are depicted 'as 'a reservoir of infection,' fuelled local constructions of AIDS as 'a disease of women,' or of the 'lower orders,' from whom the 'pure' required protection.' In addition, many of these so-called lower-class sex workers do not lead a pampered lifestyle. Unlike higher-class counterparts, they do not have the benefit of money, clothes, and extravagant gifts from wealthy customers. Most of them do not have one lover with whom they are attached but, instead, encounter hundreds of customers interested in using them only for short-term pleasure (Central Intelligence Agency 2015). Lawless, Kippax, and Crawford (1996) find that sex workers are often viewed as a potential hazard to society because their frequent changes of sex partners contribute to HIV transmission. Consequently, various institutions tend to protect men from HIV infection, although women themselves are usually more vulnerable (Wolffers 1999).

Rhodes et al. (2005, p. 1027) define the HIV risk environment as the "variety of factors exogenous to the individual that interact to increase the chances of HIV transmission." Decades of studies have found that the most important factor influencing HIV prevention and transmission is the environment in which the risk is produced (Burris et al. 2004; Rhodes 2002; Rhodes et al. 2005). Effective HIV prevention programs involve not only designing interventions that foster individual behavioral change but also the creation of local environments conducive to individual- and community-level behavioral change (Rhodes 2002; Rhodes et al. 2005). The high-risk or low-risk dimension of the environment where individuals live and work should influence individuals' intentions to use various HIV/AIDSprevention goods and services. For example, survey evidence in the United States has suggested that the prevalence of AIDS in a given state directly and positively affects the rate of use of condoms in that state (Ahituv et al. 1996).

The general assumption in welfare economics is that users of any goods that might generate positive externalities will first seek private benefits but not external benefits. Economic analysis can identify external benefits, but it usually assumes that these are either not known or of little concern to the users of the primary goods that might generate such externalities (e.g., sex workers). That is, exchange actors may not have formulated expectations about externality generation prior to exchange. Thus, users of condoms seek protection for themselves (and in some, but probably not all, cases, their partners) rather than abstract and far less visible external benefits such as "reduced prevalence among contacts" or reduced likelihood of infecting others (Cadeaux 2000; Cornes and Sandler 1986). For example, in the commercial sex industry in Indonesia, the primary benefit associated with the use of condoms is STD prevention for the users themselves (Futures Group International 2000). Thus, individuals are more likely to use condoms when they perceive the threat of HIV infection to be high for themselves (Wee et al. 2004). But external benefits also exist. For example, the use of testing services and HIV/AIDS education should plausibly increase users' knowledge of HIV and other STDs and thus restrict or reduce their sexual activities (i.e., it should yield "activity restriction"; Cadeaux 2000), which can, in turn, reduce prevalence. However, experimental research suggests that HIV testing may also result in an increase in risky sexual behavior, especially for those who otherwise face low infection risk (Sen 2004).

Prospective beneficiaries, however, may express diverse levels of demand for external benefits. In turn, they may hold diverse perceptions and attitudes about the consumption and 
use of the various goods and services that might generate these benefits. A variety of goods and services serve markets for HIV/AIDS prevention. Hypothetically, one potential basis for product differentiation for such goods and services may be the degree to which a good's use is voluntary. Another hypothetical dimension could be the degree to which a good's use is socially isolating versus socially integrating. In such a hypothetical positioning, for example, condoms may entail a more voluntary act of consumption than either HIV/AIDS education or quarantine hospitalization.

In the context of a country like Indonesia, a practice such as abstinence behavior and a service such as quarantine hospitalization may be perceived as more socially isolating than either HIV/AIDS education or condom use. Thomas (2000) classifies abstinence behavior as either primary abstinence (e.g., remaining a virgin) or secondary abstinence (e.g., returning to abstinence after sexual activity). Abstinence behavior could be socially isolating simply because its practice, to some extent, isolates its practitioners from social contact, especially social sexual contact. However, the abstinence approach is also strongly linked with tradition and conservative religion-infused public policy, while, in contrast, comprehensive sex education is associated with modernity, scientific accuracy, and/or freedom to discuss and endorse sexuality (Lesko 2010). In light of these observations, this study will empirically examine the robustness of the hypothetical positionings illustrated in Figure 1.

In general, users' perceptions of the benefits and perceptions of risk may affect their behavior toward such preventive goods and services. In particular, intention to use will be affected by beliefs about external benefits and perceived likelihood of infection. Distinct social groups or populations will have different perceptions toward various goods and services (Prata et al. 2006). In a lower-risk group, in which most individuals perceive themselves as being very unlikely to get infected by HIV/AIDS, intention to use HIV/AIDS-prevention products should be directly affected by perceived risk only and not by beliefs about external benefits. Thus, in particular:

$\mathrm{H}_{1}$ : In a lower-risk setting, perceived likelihood of infection (of self) positively affects the intention to use (a) condoms, (b) vaccines, (c) testing, and (d) HIV/AIDS education.

$\mathrm{H}_{2}$ : In a lower-risk setting, perceived likelihood of infection (of partner) positively affects the intention to use (a) condoms, (b) vaccines, (c) testing, and (d) HIV/AIDS education.

$\mathrm{H}_{3}$ : In a lower-risk setting, the belief in the external benefit of reduced prevalence does not affect the intention to use (a) condoms, (b) vaccines, (c) testing, or (d) HIV/AIDS education.

$\mathrm{H}_{4}$ : In a lower-risk setting, the belief in the external benefit of activity restriction does not affect the intention to use (a) condoms, (b) vaccines, (c) testing, or (d) HIV/AIDS education.

As in a lower-risk setting, in a higher-risk setting, perceived likelihood of infection should positively influence intentions to use various HIV/AIDS-prevention products. However, in contrast to a lower-risk setting, for those in a higher-risk setting, and especially a setting wherein people live and work in a subsistence marketplace, beliefs about external benefits should also positively influence intentions to use various HIV/AIDSprevention products. The reason why external benefits may uniquely matter to members of a subsistence marketplace follows from the theory of generalized exchange and cascading benefits. That is, these theories suggest that members of such groups may ultimately expect to receive indirect benefits from the use of preventive goods and services by others due to the dense structure of their community networks. Thus,

$\mathrm{H}_{5}$ : In a higher-risk subsistence marketplace, perceived likelihood of infection (of self) positively affects the intention to

Figure 1. Hypothetical Positioning of Generic Goods and Services with HIV-Related External Benefits

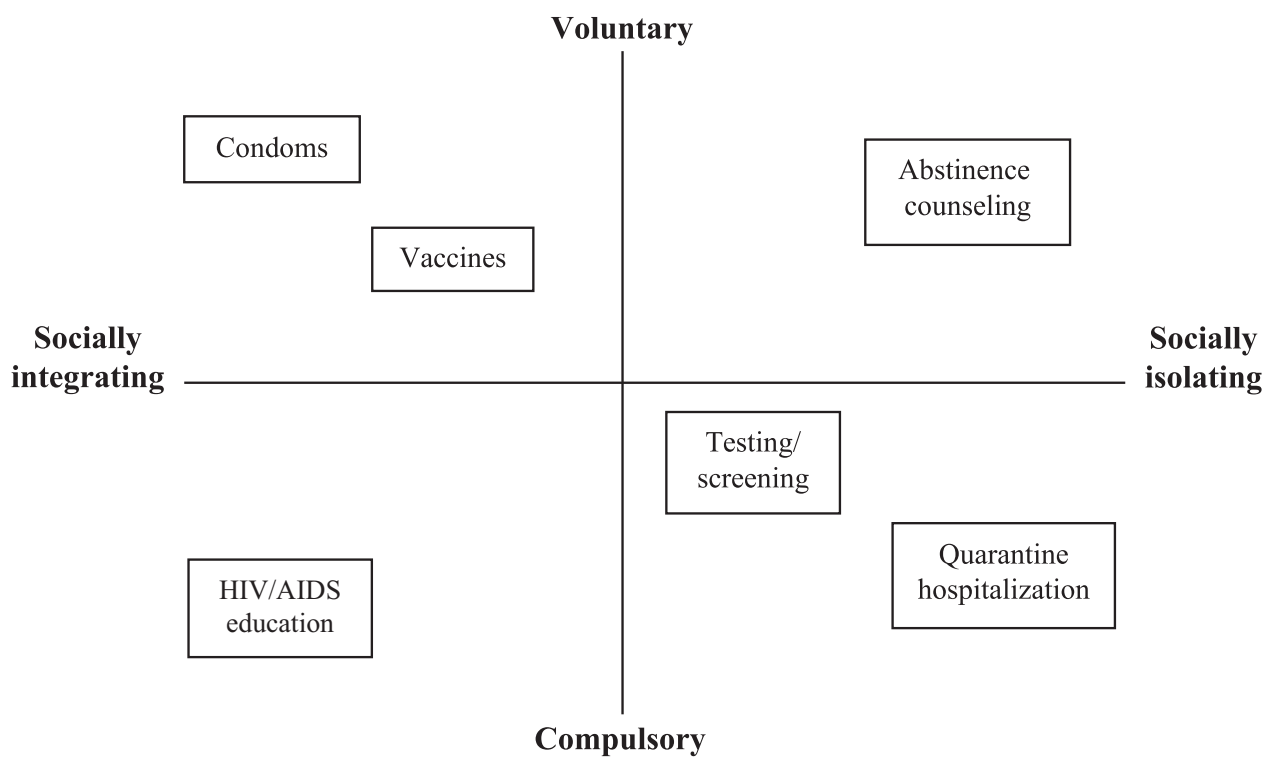

Notes: Source: Cadeaux (2000). 
use (a) condoms, (b) vaccines, (c) testing, and (d) HIV/AIDS education.

$\mathrm{H}_{6}$ : In a higher-risk subsistence marketplace, perceived likelihood of infection (of partner) positively affects the intention to use (a) condoms, (b) vaccines, (c) testing, and (d) HIV/AIDS education.

$\mathrm{H}_{7}$ : In a higher-risk subsistence marketplace, the belief in the external benefit of reduced prevalence positively affects the intention to use (a) condoms, (b) vaccines, (c) testing, and (d) HIV/AIDS education.

$\mathrm{H}_{8}$ : In a higher-risk subsistence marketplace, the belief in the external benefit of activity restriction positively affects the intention to use (a) condoms, (b) vaccines, (c) testing, and (d) HIV/AIDS education.

\section{Research Method}

\section{Research Background: Public Policy and HIV/AIDS in Indonesia}

With a population of 259 million people, Indonesia is the fourthlargest nation in the world (Population Reference Bureau 2016). Although all major religions can be found in Indonesia, $87.2 \%$ of Indonesia's citizens are registered as Muslim, making it the largest Muslim country in the world (Central Intelligence Agency 2015). Despite significant economic growth, most parts of Indonesia consist of somewhat stratified layers of subsistence marketplaces. More than 32 million Indonesians currently live below the poverty line, and approximately $50 \%$ of all households cluster around the national poverty line, with incomes at around \$22 per month (World Bank 2013). Indonesia's HIV epidemic is also one of the fastest-growing epidemics in Asia, with the thirdlargest number of people living with HIV in the region (UNAIDS 2013). Unlike in countries such as Thailand, efforts to reduce the spread of HIV through a major prevention method, the use of condoms, have been unsuccessful in Indonesia. One study reveals that in Indonesia, between 8 and 10 million men annually visited female commercial sex workers, but only about $10 \%$ of these men reported using condoms consistently (Schonhardt 2009). The present study focuses on Indonesia and induces variance in the degree to which respondents live in a subsistence marketplace by drawing samples from two distinct social strata.

\section{Survey Design}

A survey took place over an eight-week period in two locations that contain individuals from two distinct communities in Surabaya, Indonesia. To represent a non-subsistence marketplace and low-risk environment, the first location was the University of Surabaya, which represents upper- and lowermiddle-class society. In this setting, hard copies of the questionnaire were promoted and distributed in undergraduate and postgraduate classes by appointed lecturers from the University of Surabaya Faculty of Psychology and Pharmacy. To represent a subsistence marketplace containing a higher-risk community, the second location was an area of Surabaya known in English as "Dolly District" and in Indonesian as "Pasar Kembang" (which means "flower market"). Figure 2 displays an image of this location. Pasar Kembang, in itself, is a subset of a larger local marketing system that can be categorized as a subsistence marketplace. Because it is a red-light district, this area has some of the highest use of HIV infection-control
Figure 2. The Red-Light District in Pasar Kembang, Surabaya

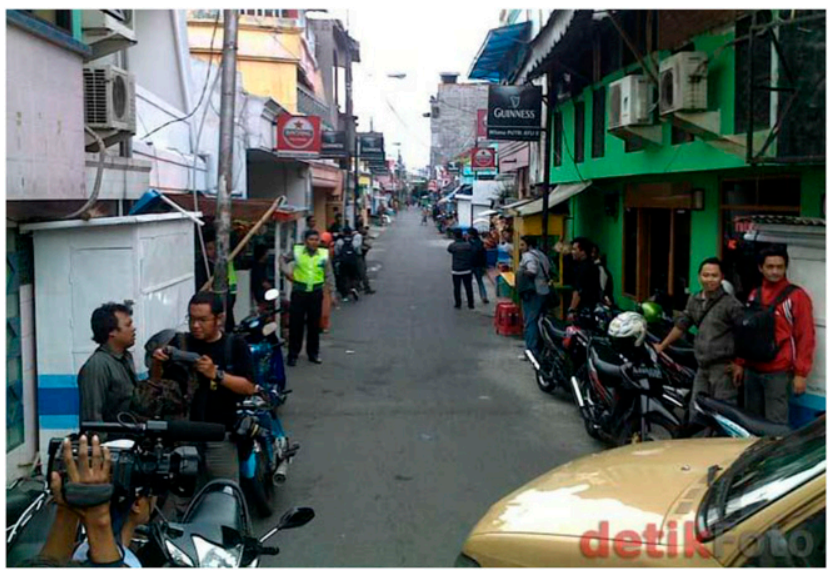

Notes: Source: www.detik.com.

products and services (i.e., condoms, abstinence counseling, HIV testing, HIV/AIDS education, and hospitalization). An estimated 1,300 lower-class sex workers live and work in what at the time of the survey was the legal red-light district of Dolly, in rather close proximity to ordinary residential neighborhoods that contain their mosques, houses, and kindergartens (Associated Press 2014). For our study, one investigator and students from the University of Surabaya distributed the questionnaires to people in the area. In addition, the questionnaires were also distributed through a nonprofit organization that works directly with the sex workers in the area. All participants were recruited on a voluntary basis. We obtained a usable sample of 612 respondents for the university sample and 256 respondents for the red-light district sample. In the red-light district, around $23.4 \%$ did not provide demographic information. Table 3 summarizes the sample profiles.

A survey instrument was divided into four sections. The first section asked respondents to indicate their likelihood to, for example, "be in need of $[\mathrm{X}]$," "request $[\mathrm{X}]$," and "use $[\mathrm{X}]$," where X was one of four products or services: condoms, vaccines, HIV testing, and education. Respondents were asked to assess the likelihood of each item on a five-point Likert scale ( 1 = "very unlikely," and 5 = "very likely"). In the second section, the survey examined the beliefs held by the segments regarding the potential for external benefits to be generated by the use of certain goods and services. This section asked respondents to indicate the extent of their beliefs that others' use of four products (i.e., condoms, vaccines, testing, and education) would yield various external benefits. It also asked respondents to express their perceived likelihood of infection for themselves and their partner. Perceived likelihood of infection was measured by a four-item scale adapted from Dijkstra, Buunk, and Blanton (2000). Typical statements included the following: "Currently, I am probably already HIV infected"; "Currently, my partner(s) is probably already HIV infected"; "In the future, I will become HIV infected"; and "In the future, my partner(s) will become HIV infected." Respondents were asked to assess the likelihood of each item on a five-point Likert scale 
Table 3. Sample Profile

\begin{tabular}{|c|c|c|}
\hline & $\begin{array}{c}\text { University } \\
(n=612)\end{array}$ & $\begin{array}{c}\text { Red-Light } \\
\text { District } \\
(\mathrm{n}=256)\end{array}$ \\
\hline \multicolumn{3}{|l|}{ Gender } \\
\hline Male & $32.5 \%$ & $56.3 \%$ \\
\hline Female & $67.5 \%$ & $43.8 \%$ \\
\hline Missing value & $0 \%$ & $0 \%$ \\
\hline \multicolumn{3}{|l|}{ Sexual Orientation } \\
\hline Straight/heterosexual & $98.0 \%$ & $45.3 \%$ \\
\hline Gay/lesbian & $.8 \%$ & $12.5 \%$ \\
\hline Bisexual/others & $1.2 \%$ & $18.4 \%$ \\
\hline Missing value & $0 \%$ & $23.4 \%$ \\
\hline \multicolumn{3}{|l|}{ Age } \\
\hline $18-24$ years & $92.3 \%$ & $12.1 \%$ \\
\hline $25-34$ years & $4.9 \%$ & $31.6 \%$ \\
\hline 35 years and older & $2.8 \%$ & $32.8 \%$ \\
\hline Missing value & $0 \%$ & $23.4 \%$ \\
\hline \multicolumn{3}{|l|}{ Education } \\
\hline Junior high school or lower & $.2 \%$ & $46.1 \%$ \\
\hline High school & $82.8 \%$ & $19.9 \%$ \\
\hline Undergraduate degree & $14.8 \%$ & $10.6 \%$ \\
\hline Postgraduate degree & $2.7 \%$ & $.4 \%$ \\
\hline Missing value & $0 \%$ & $23.4 \%$ \\
\hline \multicolumn{3}{|l|}{ Marital Status } \\
\hline Single & $81 \%$ & $4.3 \%$ \\
\hline Married & $6.4 \%$ & $19.9 \%$ \\
\hline Not married but has sexual partner(s) & $12 \%$ & $16.4 \%$ \\
\hline Separated/widowed & $.6 \%$ & $35.9 \%$ \\
\hline Missing value & $0 \%$ & $23.4 \%$ \\
\hline \multicolumn{3}{|l|}{ Income } \\
\hline Under Rp. $1,000,000$ & $65.5 \%$ & $42.6 \%$ \\
\hline Rp. $1,000,000-5,000,000$ & $30.9 \%$ & $30.9 \%$ \\
\hline Rp. $6,000,000$ and above & $3.6 \%$ & $3.1 \%$ \\
\hline Missing value & $0 \%$ & $23.4 \%$ \\
\hline \multicolumn{3}{|l|}{ Religion } \\
\hline Islam & $39.2 \%$ & $58.2 \%$ \\
\hline Christianity & $32.4 \%$ & $12.1 \%$ \\
\hline Hinduism/Buddhism & $6.1 \%$ & $2.3 \%$ \\
\hline Catholicism & $19.4 \%$ & $6.2 \%$ \\
\hline None/others & $2.9 \%$ & $.8 \%$ \\
\hline Missing value & $0 \%$ & $23.4 \%$ \\
\hline \multicolumn{3}{|l|}{ Infected by HIV? } \\
\hline No & $97.1 \%$ & $64.8 \%$ \\
\hline Yes & $0 \%$ & $13.3 \%$ \\
\hline Not sure & $2.9 \%$ & $21.9 \%$ \\
\hline Missing value & $0 \%$ & $23.4 \%$ \\
\hline
\end{tabular}

( 1 = "very unlikely," and $5=$ "very likely"). The third section was related to the perceptual mapping, which we will discuss shortly, and the final section posed several demographic questions.

The "intention-to-use" measure had Cronbach's alphas of .87 (for condoms), .95 (for vaccines), .96 (for testing), and .95 (for education). Perceived likelihood of infection had Cronbach's alphas of .86 (self) and .88 (partner). These values imply a high degree of internal consistency in the responses to the individual questions.

\section{Multidimensional Scaling}

We used multidimensional scaling to examine user perceptions and preferences toward various HIV/AIDS products and services associated with prevention and control. Two methods, an attribute-based method and a similarity-based method, exist for collecting information on consumers' perception of products. The attribute-based method is more appropriate for hard or functional attributes (price, product features) with no gap between intended and actual perceptions of the attributes; similarity-based multidimensional scaling is more appropriate for exploring the key dimensions underlying respondent's evaluation of objects (Hair et al. 1998).

The survey instrument obtained perceptions of the respondents concerning the similarity or dissimilarity of 15 pairs $[(6 \times 5) / 2]$ of six generic (not branded) products and services (i.e., vaccines, condoms, abstinence counseling, testing, HIV/AIDS education, and quarantine hospitalization). A pair, for example, might be "condoms and vaccines." Respondents rated the similarity of the elements of each pair on a six-point scale, where $1=$ "not at all similar" and $6=$ "very similar."

Responses to the 15 similarity judgments were input as separate matrices. A matrix of mean scores from two sample memberships (i.e., university and red-light district) was calculated to illustrate the general pattern of similarities (see Tables 4 and 5). With these relationships, the basic patterns can be identified and are available for comparison to the resulting map (Hair et al. 1998).

We then asked respondents to rank their preferences for the six products and services (i.e., vaccines, condoms, abstinence counseling, testing, HIV/AIDS education, and quarantine hospitalization), where a rank of 1 indicates the most preferred and a rank of 6 indicates the least preferred. We then used a series of repeated measures (see Tables 6-9) to test the equality of means within the university and red-light district samples (Hair et al. 1998). Next, we asked respondents to write one or two words that came to their mind when they read each of the phrases "using condom," "taking HIV vaccines," "receiving abstinence counseling," "undertaking HIV testing," "attending AIDS education," and "being in quarantine hospitalization." We then cross-analyzed the qualitative responses against the perceptual map results.

\section{Results and Discussion}

The findings discussed in this section refer to the two distinct groups. University students constitute the lower-risk, nonsubsistence market, and the residents of the red-light district constitute the higher-risk, subsistence market.

\section{Comparative Baseline Beliefs About External Benefits}

As a baseline analysis, respondents from the university showed significantly lower mean values than the red-light district sample regarding beliefs that the use of the selected products and services will generate each external benefit (i.e., reduced prevalence and activity restriction; see Table 10). For the external benefit of reduced prevalence, the mean scores for the university sample were $\mathrm{M}_{\mathrm{uni}}=3.67,3.81,3.55$, and 3.61, for condoms, vaccines, testing, and HIV/AIDS education, respectively. These values are all lower than the respective values for the red-light district sample: $\mathrm{M}_{\text {red-light }}=4.29,4.26,4.29$, and 4.17. In addition, the belief that these products and services will generate the external benefit of activity restriction also reveals 
Table 4. Mean Similarity Ratings for Six Items (University Sample)

\begin{tabular}{|c|c|c|c|c|c|c|}
\hline & Vaccines & Condoms & Abstinence & Testing & Education & Quarantine \\
\hline \multicolumn{7}{|l|}{ Vaccines (V) } \\
\hline Condoms (C) & 2.76 & & & & & \\
\hline Abstinence (A) & 2.65 & 2.97 & & & & \\
\hline Testing (T) & 3.27 & 2.65 & 2.73 & & & \\
\hline Education (E) & 3.12 & 3.23 & 4.47 & 3.08 & & \\
\hline Quarantine (Q) & 3.00 & 2.46 & 2.77 & 2.93 & 2.88 & \\
\hline \multicolumn{7}{|c|}{ Maximum and Minimum Similarity } \\
\hline \multicolumn{7}{|c|}{ Ratings for Each Product/ Service } \\
\hline Similarities $>4.0$ & None & None & $\mathrm{E}$ & None & A & \\
\hline Lowest similarities & $\mathrm{C}, \mathrm{A}, \mathrm{T}, \mathrm{E}, \mathrm{Q}$ & $\mathrm{V}, \mathrm{A}, \mathrm{T}, \mathrm{E}, \mathrm{Q}$ & $\mathrm{V}, \mathrm{C}, \mathrm{T}, \mathrm{Q}$ & $\mathrm{V}, \mathrm{C}, \mathrm{A}, \mathrm{E}, \mathrm{Q}$ & $\mathrm{V}, \mathrm{C}, \mathrm{T}, \mathrm{Q}$ & \\
\hline
\end{tabular}

Notes: Similarity ratings are measured on a six-point scale ( $1=$ "not at all similar," and $6=$ "very similar").

significant differences. Respondents from the university again showed significantly lower mean values than the red-light district sample regarding this belief: $\mathrm{M}_{\mathrm{uni}}=2.98,3.05$, 3.12, and 3.14; $\mathrm{M}_{\text {red-light }}=3.54,3.56,3.55$, and 3.59; for condoms, vaccines, testing, and HIV/AIDS education, respectively. Respondents from the university were less likely to use all of the selected products and services than respondents from the red-light district: $\mathrm{M}_{\mathrm{uni}}=3.32,2.46,3.27$, and 3.73; $\mathrm{M}_{\text {red-light }}=4.10,3.76,4.08$, and 4.16; for condoms, vaccines, testing, and HIV/AIDS education, respectively.

These baseline results provide very basic support for the broad view discussed earlier that members of a subsistence marketplace are more likely than those who live outside such a marketplace to believe that external benefits may realistically be manifested as cascading effects, given the relatively closer-knit social network structures in which they live and work. The fact that the residents of the red-light district are relatively more likely to use all of the prevention and control products and services may simply reflect their greater risk of exposure to HIV/AIDS, as has been demonstrated for condoms in the United States (Ahituv et al. 1996).

\section{Perceptions and Preferences for Preventive Products and Services}

The results for the university sample show that respondents perceive condoms and vaccines as dissimilar $(\mathrm{M}=2.18)(1=$ "not at all similar," and $6=$ "very similar"). In addition, they perceive condoms and vaccines differently from other products and services. Furthermore, they perceive testing and quarantine hospitalization also to be dissimilar from each other $(\mathrm{M}=2.93)$. Respondents also perceive testing and quarantine differently from other products and services (see Figure 3). In particular, the results show that respondents perceive abstinence as dissimilar to all products and services other than education $(\mathrm{M}=4.47)$. Similarly, they perceive HIV/AIDS education to be dissimilar from all products and services other than abstinence.

These findings suggest a revised perceptual positioning of these goods and services for low-risk groups in Indonesia (see Figure 4). Except for findings on condoms, the results of this study differ from the hypothetical positionings shown in Figure 1. The revised positioning of condoms could imply that condoms are perceived as voluntary and socially integrating. That is, by using condoms, people might expect to receive the benefits of reduced prevalence and reduced exposure to HIV carriers, as well as the internal and external benefit of avoidance of unwanted pregnancies, which often generate severe social consequences (e.g., shame and embarrassment). In these senses, using condoms can help maintain the social integration of users.

Indonesians seem to consider abstinence counseling a somewhat compulsory activity to the extent that abstinence itself is widely prescribed by social norms. Respondents' comments about abstinence include "[It follows] the teaching

Table 5. Mean Similarity Ratings for Six Items (Red-Light District Sample)

\begin{tabular}{|c|c|c|c|c|c|c|}
\hline & Vaccines & Condoms & Abstinence & Testing & Education & Quarantine \\
\hline \multicolumn{7}{|l|}{ Vaccines $(\mathrm{V})$} \\
\hline Condoms (C) & 2.18 & & & & & \\
\hline Abstinence (A) & 2.65 & 2.57 & & & & \\
\hline Testing (T) & 4.09 & 2.70 & 3.04 & & & \\
\hline Education (E) & 2.73 & 3.15 & 4.91 & 3.09 & & \\
\hline Quarantine (Q) & 2.61 & 2.36 & 2.92 & 3.07 & 3.13 & \\
\hline \multirow{2}{*}{\multicolumn{7}{|c|}{$\begin{array}{l}\text { Maximum and Minimum Similarity Ratings for } \\
\text { Each Product/ Service }\end{array}$}} \\
\hline & & & & & & \\
\hline Similarities $>4.0$ & $\mathrm{~T}$ & None & $\mathrm{E}$ & None & None & \\
\hline Lowest similarities & $\mathrm{C}, \mathrm{A}, \mathrm{E}, \mathrm{Q}$ & $\mathrm{V}, \mathrm{A}, \mathrm{T}, \mathrm{E}, \mathrm{Q}$ & $\mathrm{V}, \mathrm{C}, \mathrm{T}, \mathrm{Q}$ & $\mathrm{C}, \mathrm{A}, \mathrm{E}, \mathrm{Q}$ & $\mathrm{V}, \mathrm{C}, \mathrm{T}, \mathrm{Q}$ & \\
\hline
\end{tabular}

Notes: Similarity ratings are measured on a six-point scale $(1=$ "not at all similar," and $6=$ "very similar"). 
Table 6. Repeated Preference Measure (University Sample)

\begin{tabular}{lcc} 
Product/Service (Rank) & M & SD \\
\hline Vaccines (1) & 2.65 & 1.69 \\
HIV/AIDS education (2) & 2.91 & 1.50 \\
Abstinence counseling (3) & 3.04 & 1.87 \\
Condoms (4) & 3.35 & 1.64 \\
Testing/screening (5) & 3.51 & 1.37 \\
Quarantine hospitalization (6) & 5.16 & 1.32 \\
\hline
\end{tabular}

Notes: $\mathrm{N}=291$.

of a religion" and "It's the current norm." A reason why Indonesians might consider an act of abstinence compulsory is that sex outside marriage is forbidden by most state-sanctioned religions. In general, virginity is still considered an important concept in Indonesia. Abstinence conforms to the notions acknowledged in the Koran and the Bible of keeping girls "pure" and "honorable." Many Indonesians consider nonvirginity in young women to be a stigma and unmarried nonvirgin women to be "trash" (Champagne, Alvania, and Crisovan 2002). In general, abstinence is still preferred by some university students.

Moreover, HIV/AIDS education and abstinence are perceived as similar; both relate to acquiring knowledge about safe sex practices. However, AIDS educators in Indonesia are regularly forced to refrain from discussing safe sex practices in their HIV/AIDS-prevention messages because of objections from the country's small but increasingly outspoken Islamic fundamentalist groups. The country's highest Islamic authority, the Indonesian Ulemas Council, urges Muslims to fight HIV/ AIDS by being more religious and closer to family and society (Terdman and Paz 2007), and many Indonesians view HIV/ AIDS education, which often promotes the use of condoms, as encouraging sinful behavior (Prystay and Mapes 2004). In addition, as has been found in other countries, some parents are also generally opposed to their children receiving comprehensive sex education in school (Campero et al. 2010; Pick, Givaudan, and Brown 2000). In a country that has had a successful family planning program (Bongaarts 2014; Smyth 1992; Warwick 1986), condoms have often been seen as items that are used only by sex workers or that suggest infidelity. Many religious groups have publicly condemned condom promotions, declaring that their ministries would not promote condoms because of their belief that condoms encourage promiscuity (Guardian 2012). Under government policies on family planning, Indonesians perceive condoms as the least appropriate form of family planning. In fact, until the 1990s, condoms were illegal in Indonesia unless prescribed to a married couple by a physician. In the qualitative analysis of this study, the comments about HIV/AIDS education were generally quite positive. For example, respondents comment that HIV/AIDS education is "important to gain knowledge" and "very useful." Moreover, HIV/AIDS education is the second-most preferred product or service of university students, after the hypothetical product, vaccines.

In the perceptual map, we propose that vaccines and testing will be perceived as socially isolating and also as voluntary. Vaccines might be considered socially isolating because people who would need HIV vaccines might tend to get involved in risky sexual behaviors that violate social norms. Testing could also isolate an individual due to the social stigmas associated with the disease: individuals suspected of being HIV-positive are often discriminated against and are shunned by family, peers and the wider community. Comments from the qualitative analysis include statements that HIV testing is needed "to provide evidence that we are clean from HIV," "if something is wrong," and "if a person is constantly changing partners."

Finally, quarantine hospitalization is the least preferred option. As previously discussed, AIDS patients already suffer from stigma and discrimination. Such patients may have already been shunned by their family and community.

In the red-light district, respondents also perceive condoms and vaccines as dissimilar $(M=2.18)$. However, they perceive vaccines and testing as similar $(\mathrm{M}=4.09)$. Compared with the university sample, condoms and vaccines have closer positionings in the red-light district sample. Moreover, in a higherrisk population, testing and quarantine hospitalization are perceived as similar $(M=3.07)$. The perceptual map does not show close positionings here. As in the previous sample, abstinence and education are also perceived as similar $(\mathrm{M}=$ 4.91), with close positionings (see Figure 5).

In the university sample, the ranking shows that respondents have the strongest preference for vaccines $(M=2.65)$, followed by HIV/AIDS education ( $\mathrm{M}=2.91)$ and abstinence counseling $(\mathrm{M}=3.044)$. Condoms $(\mathrm{M}=3.35)$, testing $(\mathrm{M}=3.51)$, and quarantine hospitalization $(\mathrm{M}=5.16)$ are least preferred (see Table 5). Furthermore, with regard to perceptual positioning, we also propose a new hypothetical positioning for the high-risk group from the subsistence marketplace (see Figure 6). As shown by the data, the main positioning difference between the low-risk and the high-risk group is the positioning of testing and vaccines. In the high-risk population, testing is perceived as a socially isolating and voluntary. As noted previously, most people with AIDS suffer from "perceived" and "enacted" stigma (Brown, Macintyre, and Trujillo 2003; Jacoby 1994). Therefore, most sex workers in Indonesia have been afraid to learn their HIV status because of the extreme social stigmas associated with the disease. Testing still depends on each individual's willingness to be tested. Individuals suspected of being HIV-positive are often forced out of communities because

Table 7. Mauchly Test of Sphericity (University Sample)

\begin{tabular}{lcccccccc}
$\begin{array}{l}\text { Within-Subject } \\
\text { Effect }\end{array}$ & Mauchly's W & $\begin{array}{c}\text { Approximate } \\
\text { Chi-Square }\end{array}$ & d.f. & Significance & & \multicolumn{3}{c}{ Epsilon a } \\
\cline { 5 - 9 } Preference & .603 & 145.969 & 14 & .000 & .816 & .200 & Huynh-Feldt & Lower Bound
\end{tabular}


Table 8. Repeated Preferences Measure (Red-Light District Sample)

\begin{tabular}{lcc} 
Product/Service (Rank) & M & SD \\
\hline Condoms (1) & 2.04 & 1.41 \\
HIV/AIDS education (2) & 2.72 & 1.60 \\
Vaccines (3) & 2.78 & 1.94 \\
Testing/screening (4) & 2.94 & 1.41 \\
Abstinence counseling (5) & 3.99 & 1.74 \\
Quarantine hospitalization (6) & 4.81 & 1.73
\end{tabular}

Notes: $\mathrm{N}=127$.

of fears of infection harbored by the rest of the community or because clients will become fearful of contact with any of the sex workers there, which could lead to a pecuniary external cost in lost business (Mutahar 2011; Sugihantono et al. 2003).

Consequently, sex workers, especially women who have become infected with HIV, may find they are being stigmatized by both their profession and their health status, making them susceptible to the human rights violations that have come to be associated with HIV/AIDS and that affect people's willingness to undergo testing and adherence to antiretroviral therapy (UNAIDS 2002, 2009; Wariki et al. 2010). Therefore, examining perceptions to reduce stigma and discrimination is a necessary step for a successful HIV-prevention program.

Table 8 shows that respondents from the red-light district most strongly prefer condoms $(\mathrm{M}=2.04)$ and have significantly lower preferences for testing $(M=2.94)$, abstinence $(M=3.99)$, and quarantine hospitalization $(\mathrm{M}=4.81)$. Globally, HIV testing rates remain low (He et al. 2009). The World Health Organization (2013) estimates that only $10 \%$ of people infected with HIV know their HIV status, despite the fact that HIV voluntary counseling and testing is the central focus in HIV prevention in developing and developed countries (Bateganya, Abdulwadud and Kiene 2010; De Zoysa et al 1995; Summers et al. 2000). However, most sex workers in Indonesia suffer from lack of access to health, social, and legal services.

As suggested by Morin et al. (2006), the inconvenience of testing location hours may contribute to people not being tested. Manirankunda et al. (2009) also suggest that positive test results may expose individuals to stigma, discrimination, and missed opportunities. Abstinence counseling could be perceived as compulsory but also as helping integrate a participant into society. However, since the commercial nature of sex work involves sex with clients, sex workers do not view abstinence or reducing the number of sexual partners as desirable.

Respondents in the red-light district sample could plausibly perceive condom usage as a voluntary and socially integrating act. Their preference for condoms is exemplified in comments such as "[Condoms] will prevent us the possibility of being infected by HIV" and "[When] changing partners, [condoms are] a must." However, most clients are reluctant to use condoms despite sex workers' expectation that they help prevent HIV infection. One study shows that male sex workers are more likely than female sex workers to report condom use with their clients (National AIDS Commission Republic of Indonesia 2009). Another reason for low condom usage in Indonesia is lack of political support. Many Indonesian policy makers do not want to be seen as supporting and encouraging condom use, which is against most conservative and religious ideologies in Indonesia (National AIDS Commission Republic of Indonesia 2009). Many countries, including the well-known example of Thailand, actively promote condom use to prevent HIV/AIDS infection; however, the Indonesian government has not actively promoted condom use and has claimed that condoms have low efficacy in preventing pregnancy (Saifuddin 1980). Thus, Indonesia has one of the lowest condom usage rates among Asian countries (Osman 2011). Although condoms are available in pharmacies and convenience stores around Indonesia, many potential users are often embarrassed or afraid of being seen purchasing them. Other studies in developed countries also suggest that consumers may still be reluctant to buy condoms due in part to embarrassment (Prevel Katsanis 1994; Rouland 1996). Currently, most condom-use programs in Indonesia are limited to distribution in recognized hot spots and localized brothel areas (National AIDS Commission Republic of Indonesia 2009). Adding to the incongruity of perceptions among users, in some districts of Indonesia (e.g., Aceh), a woman is prosecuted on prostitution charges if she is caught in possession of a condom. Legislation that criminalizes people living with or vulnerable to HIV infection fuels stigma and discrimination in many countries, including Indonesia (Magnani et al. 2010; Schonhardt 2009). Moreover, another challenge in selling condoms in Indonesia is the perception that sex with a condom is not pleasurable.

Respondents from the red-light district also consider quarantine hospitalization to be the least preferred option. In Indonesia, hospitals and health care workers often refuse to provide care to HIV-positive patients; they may postpone treatments and even reveal blood test results to other people without the patient's permission (AMFAR 2005). Thus, potential users may not trust hospitals as institutions for HIV prevention.

\section{The Effects of Perceived Infection Risk and External Benefits Beliefs on Use Intentions}

In the lower-risk university environment, perceived likelihood of infection does not explain individuals' intentions to use condoms, vaccines, HIV testing, or education. These results fail to support $\mathrm{H}_{1 \mathrm{a}}, \mathrm{H}_{1 \mathrm{~b}}, \mathrm{H}_{1 \mathrm{c}}$, and $\mathrm{H}_{1 \mathrm{~d}}$. HIV infection rates among

Table 9. Mauchly Test of Sphericity (Red-Light District Sample)

\begin{tabular}{lccccccc} 
Within-Subjects & & & & \multicolumn{3}{c}{ Epsilon a } \\
\cline { 5 - 7 } Effect & Mauchly's W & $\begin{array}{c}\text { Approximate } \\
\text { Chi-Square }\end{array}$ & d.f. & Significance & Greenhouse-Geisser & Huynh-Feldt & Lower Bound \\
\hline Preference & .356 & 128.179 & 14 & .000 & .736 & .761 & .200 \\
\hline
\end{tabular}


Table 10. Mean Differences Between Red-Light District and University

\begin{tabular}{|c|c|c|c|c|}
\hline & University & Red-Light District & $\mathbf{F}$ & Significance \\
\hline \multicolumn{5}{|c|}{$\begin{array}{l}\text { Beliefs About Generating External Benefit of } \\
\text { Reduced Prevalence }\end{array}$} \\
\hline Condoms & 3.67 & 4.29 & 1.226 & .000 \\
\hline Vaccines & 3.81 & 4.26 & .871 & .000 \\
\hline Testing & 3.55 & 4.29 & .463 & .000 \\
\hline HIV/AIDS education & 3.61 & 4.17 & .218 & .000 \\
\hline \multicolumn{5}{|c|}{$\begin{array}{l}\text { Beliefs About Generating External Benefit of } \\
\text { Activity Restriction }\end{array}$} \\
\hline Condoms & 2.98 & 3.54 & 34.26 & .000 \\
\hline Vaccines & 3.05 & 3.56 & 24.21 & .000 \\
\hline Testing & 3.12 & 3.55 & 40.58 & .000 \\
\hline HIV/AIDS education & 3.14 & 3.59 & 23.48 & .000 \\
\hline \multicolumn{5}{|l|}{ Intention to Use $\mathrm{U}^{\mathrm{b}}$} \\
\hline Condoms & 3.32 & 4.10 & .656 & .000 \\
\hline Vaccines & 3.46 & 3.76 & .522 & .032 \\
\hline Testing & 3.27 & 4.08 & 9.850 & .000 \\
\hline HIV/AIDS education & 3.73 & 4.16 & 4.356 & .000 \\
\hline
\end{tabular}

aRating scale: 1 = "strongly disagree," and 5 = "strongly agree."

bRating scale: 1 = "very unlikely," and 5 = "very likely."

university students in Indonesia are relatively low and, perhaps consequently, have little potential to affect students' intentions to use these goods and services. Similarly, and for perhaps the same reasons, the knowledge of a partner being infected by HIV does not significantly explain individuals' intentions to use condoms, vaccines, HIV testing, or education. These results also fail to support $\mathrm{H}_{2 \mathrm{a}}, \mathrm{H}_{2 \mathrm{~b}}, \mathrm{H}_{2 \mathrm{c}}$, and $\mathrm{H}_{2 \mathrm{~d}}$.

The results for beliefs about external benefit generation show that an expectation for reduced prevalence positively affects lower-risk community members' intentions to use condoms $(\beta=.333, p=.000)$, vaccines $(\beta=.376, p=.000)$, HIV testing $(\beta=.260, p=.000)$, and education $(\beta=.261, p=.000)$. Thus, $\mathrm{H}_{3 \mathrm{a}}, \mathrm{H}_{3 \mathrm{~b}}, \mathrm{H}_{3 \mathrm{c}}$, and $\mathrm{H}_{3 \mathrm{~d}}$ are not supported. However, the external benefit of activity restriction does not explain individuals' intentions to use condoms, vaccines, or HIV testing. These results do support $\mathrm{H}_{4 \mathrm{a}}, \mathrm{H}_{4 \mathrm{~b}}$, and $\mathrm{H}_{4 \mathrm{c}}$.

Finally, activity restriction positively explains individuals' intentions to use HIV/AIDS education. This result fails to

Figure 3. Two-Dimensional Perceptual Map: University Sample

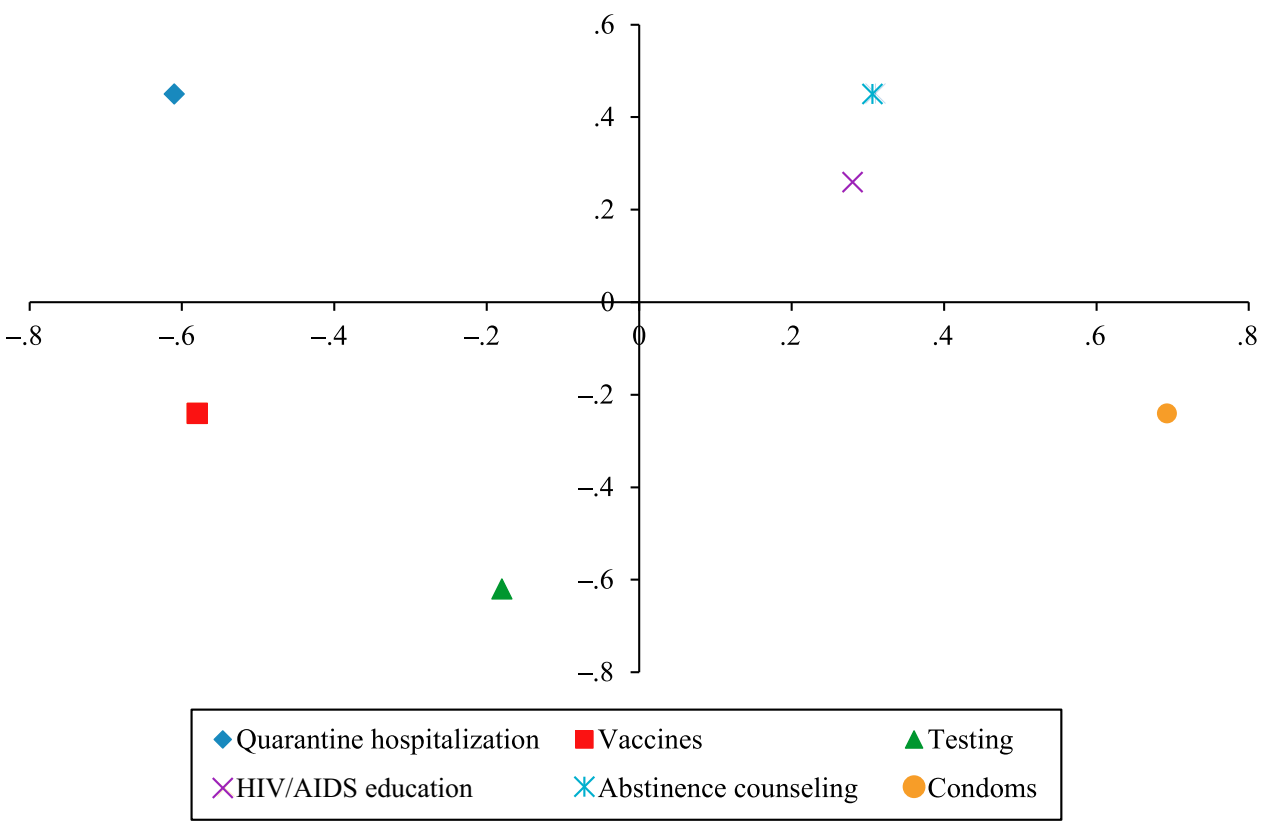


Figure 4. Low-Risk Group's Hypothetical Positioning of Generic Goods and Services with HIV-Related External Benefits

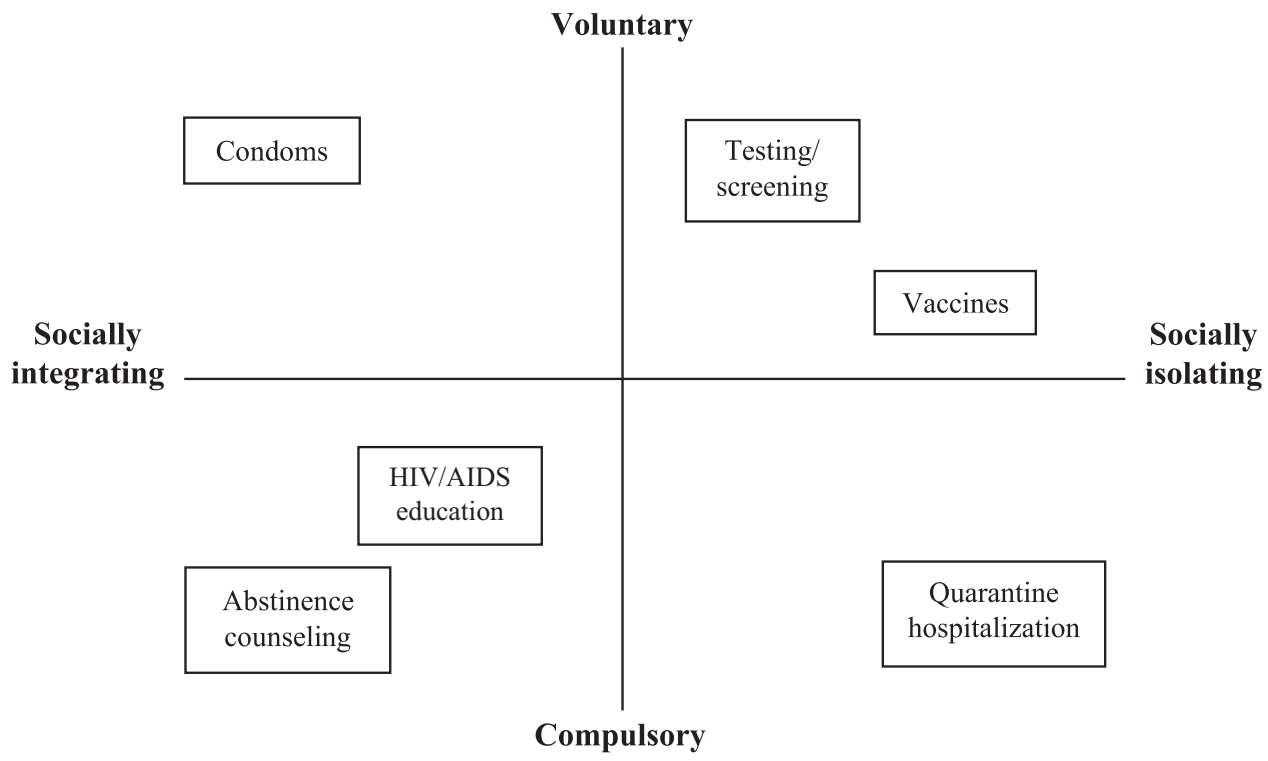

support $\mathrm{H}_{4 \mathrm{~d}}$. Table 11 summarizes the regression results for the university sample.

In the subsistence marketplace, the analysis of perceived likelihood of infection and beliefs about external benefits shows that perceived likelihood of infection (of self) has a negative effect on individuals' intentions to use testing ( $\beta=-.748, p=$ $.004)$ and education $(\beta=-.887, p=.000)$. These results fail to support $\mathrm{H}_{5 \mathrm{c}}$ and $\mathrm{H}_{5 \mathrm{~d}}$. In addition, perceived likelihood of infection (of self) has no effect on intentions to use condoms and vaccines. This result fails to support $\mathrm{H}_{5 \mathrm{a}}$ and $\mathrm{H}_{5 \mathrm{~b}}$; it also shows that individuals infected by HIV are actually less likely to use
HIV testing and education than those who are not infected. Perhaps individuals in the high-risk area perceive that these goods and services, which are claimed to prevent HIV/AIDS, are in fact inadequate to protect them from the disease. In contrast to the results for perceived likelihood of infection of self, in this higher-risk group, the results show that perceived likelihood of infection of partner does positively affect individuals' intentions to use HIV testing $(\beta=.772, p=.003)$ and education $(\beta=-.611, p=.015)$. These results support $\mathrm{H}_{6 \mathrm{c}}$ and $\mathrm{H}_{6 \mathrm{~d}}$. Nonetheless, perceived likelihood of infection (of partner) has no effect on intentions to use condoms and vaccines. Thus,

Figure 5. Two-Dimensional Perceptual Map: Red-Light District Sample

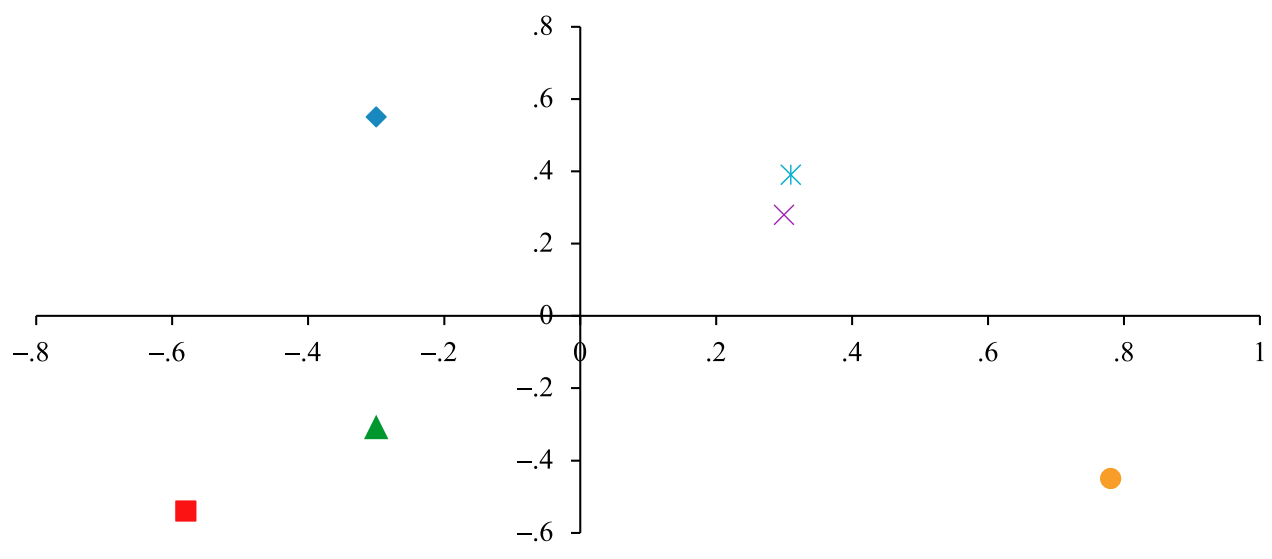

$\begin{array}{lll}\diamond \text { Quarantine hospitalization } & \square \text { Vaccines } & \Delta \text { Testing } \\ \times \text { HIV/AIDS education } & \text { *Abstinence counseling } & \text { OCondoms }\end{array}$


Figure 6. High-Risk Group's Hypothetical Positioning of Generic Goods and Services with HIV-Related External Benefits

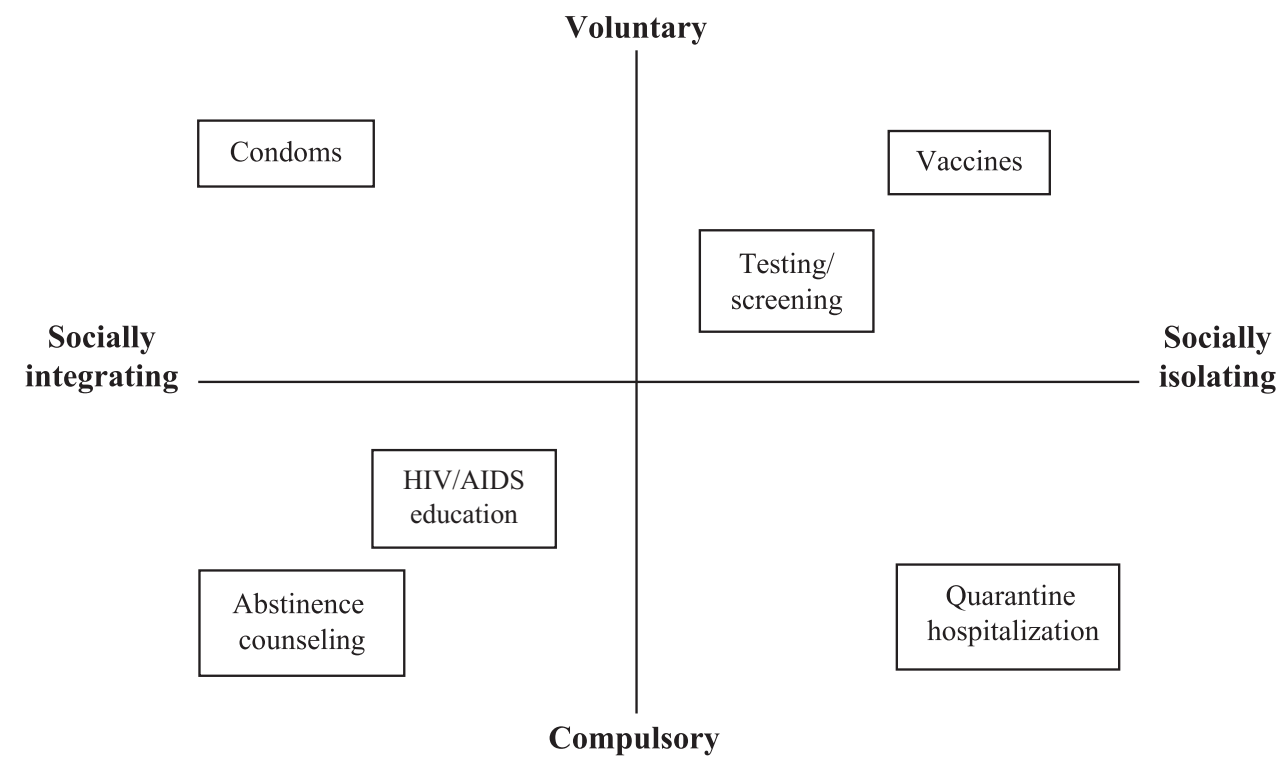

the results fail to support $\mathrm{H}_{6 \mathrm{a}}$ and $\mathrm{H}_{6 \mathrm{~b}}$. In this subsistence community, knowledge of the partner's health condition influences intentions to use HIV testing and education but not intentions to use condoms and vaccines.

The analysis of external benefits beliefs shows that reduced prevalence or the potential to avoid infecting others has a positive effect on individuals' intentions to use condoms $(\beta=$ $.290, p=.001)$, vaccines $(\beta=.205, p=.047)$, and education $(\beta=$ $.431, p=.000)$ but no effect on intentions to use HIV testing. These results support $\mathrm{H}_{7 \mathrm{a}}, \mathrm{H}_{7 \mathrm{~b}}$, and $\mathrm{H}_{7 \mathrm{~d}}$ but fail to support $\mathrm{H}_{7 \mathrm{c}}$. Beliefs about the external benefit of reduced prevalence among users positively influences users' intentions to use condoms, vaccines, and education. These results may highlight the concept of interactional empathy as well as the broader concept of cascading benefits. Invoking the former concept, a strong emphasis on the human dimensions and the needs and circumstances of each person might manifest itself in this case as empathy with the client of sex workers (Viswanathan et al. 2012). The empathy may involve Person A (the sex worker) viewing the situation of Person B (the client) from B's perspective, allowing the sex worker to feel as if B's situation is personally affecting him or her rather than someone else (Basil, Ridgway, and Basil 2008; Viswanathan et al. 2012). Although not directly tested here, this scenario may explain why intentions to use condoms, vaccines, HIV testing, and education are influenced by beliefs about external benefits.

Nonetheless, the belief about the external benefit of activity restriction positively explains individuals' intentions to use HIV testing $(\beta=.203, p=.032)$ but does not explain intentions to use condoms, vaccines, or HIV/AIDS education. Thus, these results support $\mathrm{H}_{8 \mathrm{c}}$ but not $\mathrm{H}_{8 \mathrm{a}}, \mathrm{H}_{8 \mathrm{~b}}$, or $\mathrm{H}_{8 \mathrm{c}}$. Table 12 summarizes the regression results for the red-light district sample.

Overall, the results fail to support many of the hypotheses. In the subsistence marketplace, infection by HIV does not influence intentions to use condoms, vaccines, HIV testing, or education. This finding highlights a significant risk toward
HIV-prevention efforts: sex workers are often powerless to negotiate safer sex. Moreover, laws rarely protect sex workers. Similarly, in the university sample, infection by HIV does not influence intentions to use condoms or vaccines. In Indonesia, few people view condom usage as an effective way to reduce the prevalence of HIV. The mayor of Surabaya has even forbidden the sale of contraceptives in supermarkets to people who are unmarried or are under 21 years (Pathoni 2015).

Generally, in the high-risk environment, perceived likelihood of infection appears to negatively influence individuals' intentions to use the selected goods and services. In contrast, reduced prevalence, or the potential to avoid directly infecting others, positively influences individuals' intentions to use these goods and services. Perhaps people in such environments weigh the (internal) benefits against the external consequences of their activity (Douglas 2002). Clients commonly refuse to use a condom during paid sex; using a condom may bring various physical consequences (e.g., irritation, swelling, allergic reaction) or psychological consequences (e.g., perception that the client or sex workers are sick) (Pareja 1991). Therefore, sex workers constantly face the threat of HIV/AIDS infection; if they do become infected, no amount of goods or services will be able to protect them. Some sex workers may have accepted the risk in order to generate income for themselves and the families they support. However, the broad finding in this study is that the expected external benefits associated with reduced prevalence have a positive effect on use intentions in a group that is relatively less formally educated. Perhaps the social consequences these respondents have in mind are those for their immediate social network of family and friends, rather than the wider society at large. To confirm this interpretation would require further research, but it is potentially a very important avenue for further work. Nevertheless, this interpretation is consistent with the view of Viswanathan et al. (2010, p. 535) that community members in a subsistence marketplace, although resource poor, can be "network-rich through social relations." Such an 
Table 11. Regression Analysis (University)

\begin{tabular}{|c|c|c|c|}
\hline & Standardized Beta & t-Value & Significance \\
\hline \multicolumn{4}{|c|}{ Model A: Dependent Variable $=$ Intention to Use } \\
\hline \multicolumn{4}{|c|}{ Condom ${ }^{\mathrm{a}}$} \\
\hline Constant & & 5.567 & .000 \\
\hline Infected by HIV (self) & .102 & .798 & .426 \\
\hline Infected by HIV (partner) & .006 & .046 & .964 \\
\hline Reduce prevalence & .333 & 5.774 & .000 \\
\hline Activity restriction & .010 & .167 & .867 \\
\hline \multicolumn{4}{|c|}{ Model B: Dependent Variable = Intention to Use } \\
\hline \multicolumn{4}{|c|}{ Vaccines ${ }^{b}$} \\
\hline Constant & & 2.058 & .040 \\
\hline Infected by HIV (self) & .033 & .270 & .787 \\
\hline Infected by HIV (partner) & .222 & 1.811 & .071 \\
\hline Reduce prevalence & .376 & 7.040 & .000 \\
\hline Activity restriction & .004 & .072 & .943 \\
\hline \multicolumn{4}{|c|}{ Model C: Dependent Variable = Intention to Use } \\
\hline \multicolumn{4}{|c|}{ HIV Testing ${ }^{\mathrm{c}}$} \\
\hline Constant & & 4.185 & .000 \\
\hline Infected by HIV (self) & .149 & 1.192 & .234 \\
\hline Infected by HIV (partner) & .213 & 1.705 & .089 \\
\hline Reduce prevalence & .260 & 4.281 & .000 \\
\hline Activity restriction & -.046 & -.754 & .452 \\
\hline \multirow{2}{*}{\multicolumn{4}{|c|}{$\begin{array}{l}\text { Model D: Dependent Variable = Intention to Use } \\
\text { HIV/AIDS Education }\end{array}$}} \\
\hline & & & \\
\hline Constant & & 6.283 & .000 \\
\hline Infected by HIV (self) & -.078 & -.619 & .536 \\
\hline Infected by HIV (partner) & .236 & 1.868 & .063 \\
\hline Reduce prevalence & .261 & 4.489 & .000 \\
\hline Activity restriction & .154 & 2.660 & .008 \\
\hline
\end{tabular}

aModel $\mathrm{A}: \mathrm{R}^{2}=.129 ;$ adjusted $\mathrm{R}^{2}=.118 ; \mathrm{F}=11.492, p=.000$.

bModel $\mathrm{B}: \mathrm{R}^{2}=.213$; adjusted $\mathrm{R}^{2}=.203 ; \mathrm{F}=21.098, p=.000$.

cModel C: $\mathrm{R}^{2}=.170 ;$ adjusted $\mathrm{R}^{2}=.159 ; \mathrm{F}=15.937, p=.000$.

dModel $\mathrm{D}: \mathrm{R}^{2}=.146 ;$ adjusted $\mathrm{R}^{2}=.135 ; \mathrm{F}=13.312, p=.000$.

Notes: Boldface indicates significant values.

interpretation also broadly supports the theory that cascading benefits may be present and taken into account by members of dense networks as found in a subsistence market.

\section{Conclusion}

\section{Integrated Implications for Theory, Public Policy, and Marketing}

Investigating high-risk groups in a subsistence market such as a community of sex workers and their clients can offer important insights not only for the theory of externality in marketing but also for government policy and community involvement strategies for corporations and other organizations. For the government, it presents an opportunity to design an appropriate policy to increase the use of various HIV-prevention products or services that can decrease the infection rate among sex workers and their clients. For corporations, it presents an opportunity to transfer skills and develop funding arrangements through partnerships with NGOs and other not-for-profit organizations that work with vulnerable groups. As an example of the latter, in 2014, a new Indonesia health fund was established with an initial investment of $\$ 40$ million. The funding came from several business leaders in Indonesia in partnership with the Bill and Melinda Gates Foundation and the Global Fund to Fight AIDS, Tuberculosis and Malaria (2014).

If thought of simply as a function of individual levels of awareness, knowledge, and education, the baseline finding that members of the subsistence marketplace hold relatively stronger beliefs that all four HIV/AIDS-prevention goods and services might generate the two external benefits would be surprising. However, two community-level factors may better explain the observed differences than a purely individual-level argument. First, the greater prevalence level and higher risk level in the subsistence marketplace makes the external effects simply more likely to manifest themselves among others in such a community. Second, potentially denser and tighter social networks may make the benefits of these effects more likely to be realized at some point by members of such a community, thus, in effect, internalizing the externality in an unobserved process of cascading benefits and generalized exchange.

The results of this study offer practitioners and public policy makers concerned about epidemiological control of HIV/AIDS in a country such as Indonesia a number of insights about how policies and programs for managing the use of goods and services that yield external benefits might need to vary between 
Table 12. Regression Analysis (Red-Light District)

\begin{tabular}{|c|c|c|c|}
\hline & Standardized Beta & t-Value & Significance \\
\hline \multicolumn{4}{|c|}{ Model A: Dependent Variable $=$ Intention to Use } \\
\hline \multicolumn{4}{|c|}{ Condom ${ }^{\mathrm{a}}$} \\
\hline Constant & & 4.374 & .000 \\
\hline Infected by HIV (self) & -.146 & -.587 & .558 \\
\hline Infected by HIV (partner) & .095 & .381 & .703 \\
\hline Reduce prevalence & .290 & 3.296 & .001 \\
\hline Activity restriction & .025 & .288 & .774 \\
\hline \multicolumn{4}{|c|}{ Model B: Dependent Variable = Intention to Use } \\
\hline \multicolumn{4}{|c|}{ Vaccines ${ }^{b}$} \\
\hline Constant & & 3.403 & .001 \\
\hline Infected by HIV (self) & -.308 & -1.197 & .234 \\
\hline Infected by HIV (partner) & .416 & 1.597 & .113 \\
\hline Reduce prevalence & .205 & 2.005 & .047 \\
\hline Activity restriction & .127 & 1.295 & .198 \\
\hline \multicolumn{4}{|c|}{ Model C: Dependent Variable = Intention to Use } \\
\hline \multicolumn{4}{|c|}{ HIV Testing ${ }^{\mathrm{c}}$} \\
\hline Constant & & 6.270 & .000 \\
\hline Infected by HIV (self) & -.748 & -2.937 & .004 \\
\hline Infected by HIV (partner) & .772 & 3.020 & .003 \\
\hline Reduce prevalence & .158 & 1.625 & .107 \\
\hline Activity restriction & .203 & 2.171 & .032 \\
\hline \multirow{2}{*}{\multicolumn{4}{|c|}{$\begin{array}{l}\text { Model D: Dependent Variable = Intention to Use } \\
\text { HIV/AIDS Education }\end{array}$}} \\
\hline & & & \\
\hline Constant & & 8.482 & .000 \\
\hline Infected by HIV (self) & -.887 & -3.596 & .000 \\
\hline Infected by HIV (partner) & .611 & 2.473 & .015 \\
\hline Reduce prevalence & .431 & 4.556 & .000 \\
\hline Activity restriction & -.062 & -.699 & .486 \\
\hline
\end{tabular}

aModel $\mathrm{A}: \mathrm{R}^{2}=.095 ;$ adjusted $\mathrm{R}^{2}=.066 ; \mathrm{F}=3.257, p=.014$.

bModel $\mathrm{B}: \mathrm{R}^{2}=.088 ;$ adjusted $\mathrm{R}^{2}=.058 ; \mathrm{F}=2.977, p=.022$

cModel C: $\mathrm{R}^{2}=.127 ;$ adjusted $\mathrm{R}^{2}=.099 ; \mathrm{F}=4.524, p=.002$.

dModel $\mathrm{D}: \mathrm{R}^{2}=.235 ;$ adjusted $\mathrm{R}^{2}=.210 ; \mathrm{F}=9.528, p=.000$.

Notes: Boldface indicates significant values.

segments in a developing country. In a high-risk environment such as a subsistence marketplace, people who are already infected with HIV, unfortunately, may be generally less likely to use HIV/AIDS-prevention goods and services than those who are not infected. For many people, especially men, condom use implies a choice to have less pleasurable sex. Its use is still perceived as unattractive and uncomfortable, which makes women and sex workers reluctant to insist on its use (Basuki et al. 2002; Worth 1989). In addition, in the case of Indonesia, the promotion of condom use in a high-risk group appears to be a moral rather than a public health issue. In such a context, government agencies might work with religious leaders to promote abstinence and faithfulness among low-risk groups, and non-religion-based institutions or advocacy groups might promote safe sex to high-risk groups.

Nevertheless, social marketing efforts and promotion campaigns are not the core foci for the policy implications of this study. Instead, concerning, for example, the high-risk group, public policy makers in Indonesia could, hypothetically, impose a mandatory condom use policy for female sex workers. However, local authorities in Indonesia have done almost precisely the opposite: instead of mandating use, they have instead acted to limit the availability of condoms and even partially prohibit their use. A 180-degree shift from prohibition to compulsion seems quite unreasonable. Moreover, neither policy is a market mechanism; both are strictly coercive.

This study also compares a range of relevant HIV/AIDSprevention products and services that might provide opportunities for substitution or complementarity in use. Specifically, for a given individual's perceptions, a close positioning between two products or services in maps such as those in Figures 4 and 5 could suggest that the goods might be generic substitutes-inuse. For example, a sex worker might derive benefits from his or her own use of a condom as well as from both the reduced HIV prevalence among contacts and the reduced exposure to HIV carriers that would result from others' use of testing services. A number of studies have found that condoms are more likely to be used by sex workers for "sex at work" than for "personal sex." In that sense, condoms serve as a symbolic barrier between sex at work versus sex in private life (Browne and Minichielo 1995; Cusick 1998; Jackson, Highcrest, and Coates 1992; Morse et al. 1991; Pyett, Haste, and Snow 1996). Although condom use may appear to detract to some extent from the commercial aspirations of sex workers in Indonesia, the display of HIV test results to clients would not. As a perceived substitute in external benefit generation, such a display would not 
only be a market mechanism but is highly consistent with widespread practices used in Indonesia and sanctioned by various levels of government concerned with monitoring the safety and integrity of the food supply through certification programs.

The findings of this study also show that respondents from both the university and the red-light district samples strongly prefer HIV/AIDS education to the other products and services. Unfortunately, HIV/AIDS education is still lacking in Indonesia. Parents and improperly trained instructors are generally unwilling to provide even general sex education, especially to youth, due to denial and shame (UNESCO 2010). By understanding the perceptual positioning of various HIV/AIDSprevention products and services, Indonesian policy makers might consider comprehensive sex education in the school setting and in high-risk areas, rather than just the promotion of abstinence.

The results also quite broadly illustrate users' heterogeneous demand for condoms, vaccines, testing, and HIV/AIDS education, which underlies an overlap between user segments and external beneficiary segments. Cadeaux (2000) argues that much of the market failure associated with external benefits of consumption arises from the economic theory assumption of supply-and-demand homogeneity in such contexts. That is, a traditional economic analysis of market failure would attempt to find an optimal (welfare maximizing) market-wide level of consumption for each good as facing homogeneous demand across users and homogeneous supply (by ignoring differentiation across substitutes). Such an analysis would then consider conventional mechanisms to subsidize (or even mandate) the consumption of goods such as condoms, vaccines, testing, or HIV/AIDS education to achieve a welfare target. Of course, not all national markets are homogeneous; they exhibit diverse perceptions and conflicting class subcultures. Yet, some may be sufficiently homogeneous for conventional consumption subsidy mechanisms to succeed. Arguably, one reason that the $100 \%$ condom use policy has been uniquely effective in Thailand and, to a lesser extent, Cambodia (Rojanapithayakorn 2006) but has not been effective elsewhere may be that those countries have relatively high perceptual homogeneity. In fact, according to the regional director of the World Health Organization HIV/AIDS program, and contrary to popular belief, social marketing played little or no role in the Thai $100 \%$ condom use program (Rojanapithayakorn 2006). Aside from its simple slogan and directive, the most critical fact seems to have been the universally subsidized distribution of free condoms. In that sense, the $100 \%$ condom use policy in Thailand resembles a pure consumption-subsidy policy in line with traditional economic theory. But such a policy may not be applicable in all markets, particularly those with greater heterogeneity or even polarized heterogeneity, such as Indonesia. In contrast, for public policy to be effective in a heterogeneous market such as Indonesia, it must move beyond a single-good/single-segment approach.

In this study, both samples show quite distinct beliefs about the generation of external benefits and intentions to use HIV/ AIDS-prevention products and services. The subsistence marketplace group reveals higher overall expectations about the belief that these products and services will generate the external benefit of reduced prevalence and activity restriction. Perhaps the fact that respondents in this group are more likely to know someone with HIV/AIDS or who has died of AIDS may influence HIV-preventive behaviors such as condom use or taking a test whose use can yield external benefits of reduced prevalence and activity restriction. In addition, the more intimate and more embedded social network and the distinctive underclass subculture of the subsistence marketplace may partially explain this difference, which, on the surface, might otherwise appear to be a form of enlightened altruism. As theorized in this article, such apparent attitudinal altruism may in fact mask a social process of cascading benefits in which acts that appear to benefit others ultimately yield real benefits for the actor. Furthermore, in contrast to secular Western society and to the extent that it is a philosophical antecedent, altruism is less plausible in the developing-country context of this study. In contrast to developed societies - where formal as well as secular philosophical antecedents about, say, altruism and freedom of choice are likely to explain significant differences in socially consequential heterogeneity, such as differences in beliefs about external benefits of HIV prevention-in less developed societies, such antecedents can be far less influential. In particular, Indonesia has a highly centralized regulatory and policy apparatus for health and education, combined with a relatively uncrystallized, yet rather homogeneous political philosophy.

In Indonesia, religion is a more relevant and powerful antecedent than political philosophy (Kadir and Horiuchi 2002; Liddle 2004). In contrast to more secular Western nations, Indonesia has formally institutionalized and even state-sanctioned religions. Six are officially recognized: Islam, Catholicism, Protestantism, Buddhism, Hinduism, and Confucianism. Thus, rather than formal or philosophical antecedents, informal antecedents (cultural, ethnic, and religious factors) are likely to be the critical sources of heterogeneity in a country such as Indonesia. In this context, it is also worth noting that the red-light sample is predominantly Muslim, whereas the university sample is not. Clearly, religious values could be an important antecedent explanation for the observed differences in expectations about external benefits, although the exact mechanism by which that might occur would require further study.

\section{Limitations and Some Future Research Possibilities}

The specific health situation, products, and setting of this study pose several limitations. First, a simple one is that the concept of an HIV vaccine was used as a purely hypothetical option; there is still no vaccine that provides effective protection against HIV. Second, the Indonesian sample has a number of unique characteristics, and the findings may not be easily generalized to other countries that have different central government policies toward HIV-infection control. For example, unlike Indonesia, Brazil's government fully supports its HIV/AIDS-prevention program through "patient rights above patent rights" (Flanagan and Whiteman 2007). This situation might affect supply and demand for HIV-prevention products and services because Brazil is able to produce several AIDS drugs locally to ensure that they are not prohibitively expensive. Thus, each country might have different public policies toward HIV-prevention programs. Third, this study compares samples from only two distinct areas (i.e., a university area, a non-subsistence market; and a red-light district, a subsistence market). It might be useful 
to examine other adults who are not involved in extramarital sexual activities or adults from other parts of the country, such as rural Indonesia, that may have different characteristics, perceptions, and behaviors. In Indonesia, Papua, in particular, might merit attention because it has the highest HIV/AIDS rates of any region (USAID 2010). Indonesia is a vast country of thousands of islands with the fourth-largest population in the world, and although public health policy objectives and directives may be centralized, real practical access to health care goods and services varies considerably. Therefore, preferences for goods and services and expectations about the external benefits associated with their use could also vary as a function of exposure if not mere access. Finally, in this study, the two samples are distinctly different religious groups. Each religion has its own values and teachings concerning sex-related behavior. Hence, each may distinctively influence individuals' perceptions toward these products and services. Future research could more comprehensively investigate the effect of these beliefs and perceptions on various sex-related behaviors, including but not limited to the use of HIV/AIDs-prevention goods and services. Such examination is important because religiosity tends to be highest in the poorest nations of the world (Crabtree 2010; Pew Research Center 2015).

\section{References}

Ahituv, Avner, Joseph Hotz, and Tomas Philipson (1996), “The Responsiveness of the Demand for Condoms to the Local Prevalence of AIDS," Journal of Human Resources, 31 (4), 869-97.

Ainsworth, Martha (1998), "Setting Government Priorities in Preventing HIV/AIDS," Finance \& Development, 35 (3), 18-21.

AMFAR (2005), “TREAT Asia Site Profile: Udaya University and Sanglah Hospital, Bali, Indonesia," http://www.amfar.org/world/ treatasia/article. .aspx id=6006.

Andriansyah, Moch (2012), "Kemensos Akan Rehabilitasi PSK di Dolly," (accessed March 20, 2015), http://www.merdeka.com/ peristiwa/kemensos-akan-rehabilitasi-psk-di-dolly.html.

Arrow, Kenneth (1963), "Uncertainty and the Welfare Economics of Medical Care," American Economic Review, 53 (5), 944-45.

Associated Press (2014), "Indonesia Shuts Down Massive Prostitution Complex," Daily Mail (June 18), http://www.dailymail.co.uk/ wires/ap/article-2661521/Indonesia-shuts-massive-prostitutioncomplex.html.

$\mathrm{Au}$, Yoris A., and Robert J. Kauffman (2001), "Should We Wait? Network Externalities, Compatibility, and Electronic Billing Adoption," Journal of Management Information Systems, 18 (2), 47-63.

Ayres, Ian, and Steven D. Levitt (1998), "Measuring Positive Externalities from Unobservable Victim Precaution: An Empirical Analysis of Lojack," Quarterly Journal of Economics, 113 (1), 43-77.

Basil, Debra, Nancy M. Ridgway, and Michael D. Basil (2008), "Guilt and Giving: The Process Model of Empathy and Efficacy," Psychology and Marketing, 25 (1), 1-23.

Basuki, Endang, Ivan Wolffers, Walter Devillé, Noni Erlaini, Dorang Luhpuri, Rachmat Hargono, et al. (2002), "Reasons for Not Using Condoms Among Female Sex Workers in Indonesia," AIDS Education and Prevention, 14 (2), 102-16.

Bateganya, Moses, Omar A. Abdulwadud, and Susan M. Kiene (2010), "Home-Based HIV Voluntary Counseling and Testing
(VCT) for Improving Uptake of HIV Testing," Cochrane Database of Systematic Reviews, 7 (7), CD006493.

Biglan, Anthony (2009), "The Role of Advocacy Organizations in Reducing Negative Externalities," Journal of Organizational Behavior Management, 29 (3/4), 215-30.

Bongaarts, John (2014), "The Impact of Family Planning Programs on Unmet Need and Demand for Contraception," Studies in Family Planning, 45 (2), 247-62.

Brent, Robert (2009), “A Cost-Benefit Analysis of a Condom Social Marketing Programme in Tanzania," Applied Economics, 41 (4), 497-509.

Brown, L., K. Macintyre, and L. Trujillo (2003), "Interventions to Reduce HIV/AIDS Stigma: What Have We Learned?" AIDS Education and Prevention, 15 (1), 49-69.

Browne, Jan, and Victor Minichiello (1995), "The Social Meanings Behind Male Sex Work: Implications for Sexual Interactions," British Journal of Sociology, 46 (4), 598-622.

Buchanan, James, and Roger Faith (1981), "Entrepreneurship and the Internalization of Externalities," Journal of Law and Economics, 24 (1), 95-112.

Burris, Scott, Kim M. Blankenship, Martin Donoghoe, Susan Sherman, Jon S. Vernick, Patricia Case, et al. (2004), "Addressing the 'Risk Environment' for Injection Drug Users: The Mysterious Case of the Missing Cop," Milbank Quarterly, 82 (1), 125-56.

Cadeaux, Jack (1995), “Alternative Marketing Strategies for Spillover Benefits: Horizontal Cooperative Promotion, Matching, and Price Bundling," Journal of Nonprofit \& Public Sector Marketing, 2 (4), 3-14.

Cadeaux, Jack (2000), "Market Mechanisms and the External Benefits of Consumption," Journal of Macromarketing, 20 (1), 11-22.

Campero, Lourdes, Dilys Walker, Erika E. Atienzo, and Juan Pablo Gutierrez (2010), "A Quasi-Experimental Evaluation of Parents as Sexual Health Educators Resulting in Delayed Sexual Initiation and Increased Access to Condoms," Journal of Adolescence, 34 (2), 215-23.

Carman, James M. (1980), "Paradigms for Marketing Theory," in Research in Marketing, Vol. 3, Jagdish N. Sheth, ed. Greenwich, CT: JAI Press, 1-36.

Central Intelligence Agency (2015), "The World Factbook: Indonesia," (accessed September 29, 2015), https://www.cia.gov/library/ publications/the-world-factbook/geos/id.html.

Champagne, Jessica, Ribka Alvania, and Piper Crisovan (2002), "Virginity in Jogja," Latitudes, 23 (December), 32-35.

Chance, Zoë, and Rohit Deshpandé (2009), "Putting Patients First: Social Marketing Strategies for Treating HIV in Developing Nations," Journal of Macromarketing, 29 (3), 220-32.

Chismar, William, and Johannes Meier (1992), "A Model of Competing Interorganizational Systems and Its Application to Airline Reservation Systems," Decision Support Systems, 8 (5), 447-58.

Cornes, Richard, and Todd Sandler (1986), The Theory of Externalities, Public Goods, and Club Goods. New York: Cambridge University Press.

Crabtree, S. (2010), "Religiosity Highest in World's Poorest Nations," Gallup (August 31), http://www.gallup.com/poll/142727/ religiosity-highest-world-poorest-nations.aspx.

Cusick, L. (1998), "Non-Use of Condoms by Prostitute Women," AIDS Care, 10 (2), 133-46.

Daudigeos, Thibault, and Bertrand Valiorgue (2011), "Conditions for Value Creation in the Marketplace Through the Management 
of CSR Issues: A Negative External Effects Framework," Business \& Society, 50 (1), 28-49.

Demsetz, Harold (1964), "The Exchange and Enforcement of Property Rights," Journal of Law and Economics, 7 (October), 11-26.

De Zoysa, I., K.A. Phillips, M.C. Kamenga, K.R. O'Reilly, M.D. Sweat, R.A. White, et al. (1995), "Role of HIV Counseling and Testing in Changing Risk Behavior in Developing Countries," AIDS, 9 (Suppl. A), S95-101.

Dijkstra, Pieternel, Bram P. Buunk, and Hart Blanton (2000), "The Effect of Target's Physical Attractiveness and Dominance on STD-Risk Perceptions," Journal of Applied Social Psychology, 30 (8), 1738-55.

Douglas, Mary (2002), Risk Acceptability According to the Social Sciences. London: Routledge.

Elmendorf, A. Edward, Eric R. Jensen, and Elizabeth Pisani (2005), "Evaluation of the World Bank's Assistance in Responding to the AIDS Epidemic: Indonesia Case Study,” World Bank Report No. 37919, http://documents.worldbank.org/curated/en/604781468135303608/ pdf/379190IND0hiv1case1study01PUBLIC1.pdf.

Felzensztein, Christian, Lars Huemer, and Eli Gimmon (2009), "The Effects of Co-Location on Marketing Externalities in the SalmonFarming Industry," Journal of Business \& Industrial Marketing, $25(1), 73-82$.

Flanagan, William, and Gail Whiteman (2007), “AIDS Is Not a Business': A Study in Global Corporate Responsibility: Securing Access to Low-Cost HIV Medications," Journal of Business Ethics, 73 (1), 65-75.

Futures Group International (2000), "The Condom Social Marketing Component of the HIV/AIDS Prevention Project (HAPP)," report, http://pdf.usaid.gov/pdf_docs/PDABW951.pdf.

Gandal, Neil (1994), "Hedonic Price Indexes for Spreadsheets and an Empirical Test for Network Externalities," RAND Journal of Economics, 25 (1), 160-70.

Gau, Roland, Edward Ramirez, Maria E. Barua, and Ricardo Gonzalez (2014), "Community-Based Initiatives and Poverty Alleviation in Subsistence Marketplaces," Journal of Macromarketing, 34 (2), 1-11.

Global Fund to Fight AIDS, Tuberculosis and Malaria (2014), "Innovative Investment in Indonesia Health Fund," press release (April 9), available at http://www.theglobalfund.org/en/news/ 2014-04-09_Innovative_Investment_in_Indonesia_Health_Fund/.

Gonzalez-Navarro, M. (2008), "Deterrence and Displacement in Auto Theft," Working Paper No. 177, Princeton University Center for Economic Policy Studies, http://www.princeton.edu/ $\sim$ ceps/workingpapers/177gonzalez-navarro.pdf.

The Guardian (2012), "Indonesia's Condom Campaign to Fight AIDS Criticised by Religious Groups," (July 24), https://www. theguardian.com/global-development/2012/jul/24/indonesiacondom-aids-religious-groups.

Hair, J., R. Tatham, R. Anderson, and W. Black (1998), Multivariate Data Analysis, 5th ed. Upper Saddle River, NJ: Prentice Hall.

Hannan, Timothy, and John M. McDowell (1984), "The Determinants of Technology Adoption: The Case of the Banking Firm," Rand Journal of Economics, 15 (3), 328-35.

He, Na, Jinling Zhang, Jinjian Yao, Xiuhong Tian, Genming Zhao, Qingwu Jiang, et al. (2009), "Knowledge, Attitudes, and Practices of Voluntary HIV Counseling and Testing Among Rural Migrants in Shanghai, China," AIDS Education and Prevention, 21 (6), $570-81$.
Jackson, Lois, Alexandra Highcrest, and Randall A. Coates (1992), "Varied Potential Risks of HIV Infection Among Prostitutes," Social Science \& Medicine, 35 (3), 281-86.

Jacoby, Ann (1994), "Felt Versus Enacted Stigma: A Concept Revisited. Evidence from a Study of People with Epilepsy in Remission," Social Science \& Medicine, 38 (2), 269-74.

Jawa, Pos (2014), "PSK Dolly Penuhi Panti Rehabilitasi Kediri," (April 6), http://www2.jawapos.com/baca/artikel/2073/psk-dollypenuhi-panti-rehabilitasi-kediri.

Jones, Gavin, Endang Sulistyaningsih, and Terence H. Hull (1995), Prostitution in Indonesia. Canberra: Australian National University Press.

Kadir, Suzaina, and Yusaku Horiuchi (2002), "Religion and Politics in Indonesia," in Occasional Paper Series, Vol. 18. Tokyo: University of Tokyo School of Oriental Studies, 4-16.

Lawless, Sonia, Susan Kippax, and June Crawford (1996), "Dirty, Diseased, and Undeserving: The Positioning of HIV Positive Women," Social Science \& Medicine, 43 (9), 1371-77.

Layton, Roger (2007), "Marketing System: A Core Macromarketing Concept," Journal of Macromarketing, 27 (3), 227-42.

Lesko, Nancy (2010), "Feeling Abstinent? Feeling Comprehensive? Touching the Affects of Sexuality Curricula," Sex Education, 10 (3), 281-97.

Levine, Sheen, and Robert Kurzban (2006), "Explaining Clustering in Social Networks: Towards an Evolutionary Theory of Cascading Benefits," Managerial and Decision Economics, 27 (2/3), 173-87.

Liddle, William (2004), "Religion and Politics in Indonesia," audio recording, Mershon Center for International Security Studies, Ohio State University, http://hdl.handle.net/1811/31988.

Magnani, Robert, Pandu Riono, Eko Saputro, Dyah Mustikawati, Atiek Anartati, Ciptasari Prabawanti, et al. (2010), "Sexual Risk Behaviours, HIV, and Other Sexually Transmitted Infections Among Female Sex Workers in Indonesia," Sexually Transmitted Infections, 86 (5), 393-99.

Mahoney, Michelle S., Simon Kemp, and Paul Webley (2005), "Factors in Lay Preferences for Government or Private Supply of Services," Journal of Economic Psychology, 26 (1), 73-87.

Manirankunda, Lazare, Jasna Loos, Thérèse Assebide Alou, Robert Colebunders, and Christiana Nöstlinger (2009), "It's Better Not to Know: Perceived Barriers to HIV Voluntary Counselling and Testing Among Sub-Saharan African Migrants in Belgium," AIDS Education and Prevention, 21 (6), 582-93.

Morin, Stephen F., Gertrude Khumalo-Sakutukwa, Edwin D. Charlebois, Janell Routh, Katherine Fritz, Tim Lane, et al. (2006), "Removing Barriers to Knowing HIV Status: Same-Day Mobile HIV Testing in Zimbabwe," Journal of Acquired Immune Deficiency Syndromes, 41 (2), 218-24.

Morse, Edward, Patricia M. Simon, Howard J. Osofsky, Paul M. Balson, and H. Richard Gaumer (1991), "The Male Street Prostitute: A Vector for Transmission of HIV Infection into the Heterosexual World," Social Science \& Medicine, 32 (5), 535-39.

Mutahar, Rini (2011), "Determinants of Indonesian People Attitudes Towards People Living with HIV/AIDS (PLWHA)," International Journal of Public Health Research, 2011 (Special Issue), 224-28.

Nason, Robert (1989), "The Social Consequences of Marketing: Macromarketing and Public Policy," Journal of Public Policy \& Marketing, 8 (Spring), 242-51.

National AIDS Commission Republic of Indonesia (2009), "Republic of Indonesia Country Report on the Follow Up to the 
Declaration of Commitment on HIV/ AIDS (UNGASS): Reporting Period 2008-2009," http://data.unaids.org/pub/Report/2010/ indonesia_2010_country_progress_report_en.pdf.

Osman, Nurfika (2011), "Most 'High-Risk' Men Reject Condom Use, Indonesia Government Says," Jakarta Globe (January 21), http://jakartaglobe.id/archive/most-high-risk-men-reject-condomuse-indonesia-government-says/.

Pareja, Reynaldo (1991), "Why Clients of Sex Workers Don't Use Condoms," AIDSCOM Project, http://pdf.usaid.gov/pdf_docs/ PNABL865.pdf.

Pastine, Ivan, and Tuvana Pastine (2011), "Coordination in Markets with Consumption Externalities: Advertising and Product Quality," The Manchester School, 79 (1), 45-62.

Pathoni, Ahmad (2015), "Indonesia City Aims to Restrict Condoms Sales," Indonesia Real Time (blog), The Wall Street Journal (February 19), http://blogs.wsj.com/indonesiarealtime/2015/02/ 19/indonesian-city-aims-to-restrict-condoms-sales/.

Pew Research Center (2015), "The Future of World Religions: Population Growth Projections, 2010-2050," Demographic Study (April 2), http://www.pewforum.org/2015/04/02/religious-projections2010-2050/.

Pick, Susan, Martha Givaudan, and Jeremy Brown (2000), "Quietly Working for School-Based Sexuality Education in Mexico: Strategies for Advocacy," Reproductive Health Matters 8 (16), 92-102.

Population Reference Bureau (2016), "2016 World Population Data Sheet," http://www.prb.org/Publications/Datasheets/2016/2016world-population-data-sheet.aspx.

Prata, Ndola, Leo Morris, Elizio Mazive, Farnaz Vahidnia, and Mark Stehr (2006), "Relationship Between HIV Risk Perception and Condom Use: Evidence from a Population-Based Survey in Mozambique," International Family Planning Perspectives, 32 (4), 192-200.

Prevel Katsanis, Lea (1994), "Do Unmentionable Products Still Exist? An Empirical Investigation," Journal of Product \& Brand Management, 3 (4), 5-14.

Prystay, Cris, and Timothy Mapes (2004), "In Indonesia, AIDS Education Clashes with Islam," TheBody.com (March 26), http:// www.thebody.com/content/prev/art26421.html.

Pyett, Priscilla, Ben Haste, and J. Snow (1996), "Risk Practices for HIV Infection and Other STDs Amongst Female Prostitutes Working in Legalized Brothels," AIDS Care, 8 (1), 85-94.

Rhodes, Tim (2002), "The 'Risk Environment': A Framework for Understanding and Reducing Drug-Related Harm," International Journal on Drug Policy, 13 (2), 85-94.

Rhodes, Tim, Merrill Singer, Philippe Bourgois, Samuel R. Friedman, and Steffanie A. Strathdee (2005), "The Social Structural Production of HIV Risk Among Injecting Drug Users," Social Science \& Medicine, 61 (5), 1026-44.

Rojanapithayakorn, Wiwat (2006), "The 100\% Condom Use Programme in Asia," Reproductive Health Matters, 14 (28), 41-52.

Rosen, Harvey (1988), Public Finance, 2nd ed. Homewood, IL: Irwin.

Rouland, R.C. (1996), “Condoms: Unleashed," Retail Merchandiser, 36 (10), 72-75.

Saifuddin, Abdul (1980), "Overview of Sexually Transmitted Diseases in Indonesia," British Journal of Venereal Diseases, 56 (5), 282-84.
Saloner, Garth, and Andrea Shepard (1995), "Adoption of Technologies with Network Effects: an Empirical Examination of the Adoption of Automated Teller Machines," RAND Journal of Economics, 26 (3), 479-501.

Schoepf, Brooke G. (2001), "International AIDS Research in Anthropology: Taking a Critical Perspective on the Crisis," Annual Review of Anthropology, 30 (10), 335-61.

Schonhardt, Sara (2009), "Condom Friction in Pious Indonesia," Asia Times (December 2), http://www.atimes.com/atimes/Southeast_ Asia/KL02Ae01.html.

Sedyaningsih-Mamahit, Endang, and Steven L. Gortmaker (1999), "Determinants of Safer-Sex Behaviors of Brothel Female Commercial Sex Workers in Jakarta, Indonesia," Journal of Sex Research, 36 (2), 190-97.

Sen, Sankar (2004), "The Behavioral Consequences of HIV Testing: An Experimental Investigation," Journal of Public Policy \& Marketing, 23 (Spring), 28-42.

Shankar, Venkatesh, and Barry L. Bayus (2003), "Network Effects and Competition: An Empirical Analysis of the Home Video Game Industry," Strategic Management Journal, 24 (4), 375-84.

Sloan, Frank A. (2012), "The Economics of Vaccines," in The Oxford Handbook of the Economics of the Biopharmaceutical Industry, P.M. Danzon and S. Nicholson, eds. Oxford, UK: Oxford University Press.

Smyth, Ines (1992), "The Indonesian Family Planning Programme: A Success Story for Women?" Women's Global Network for Reproductive Rights Newsletter, 38, 13-15.

Sugihantono, A., M. Slidell, A. Syaifudin, H. Pratjojo, I.M. Utami, T. Sadjimin, et al. (2003), "Syphilis and HIV Prevalence Among Commercial Sex Workers in Central Java, Indonesia: RiskTaking Behavior and Attitudes That May Potentiate a Wider Epidemic," AIDS Patient Care and STDs, 17 (11) 595-600.

Summers, Todd, Freya Spielberg, Chris Collins, and Thomas Coates (2000), "Voluntary Counseling, Testing, and Referral for HIV: New Technologies, Research Findings Create Dynamic Opportunities," Journal of Acquired Immune Deficiency Syndromes, 25 (Suppl. 2), S128-35.

Takahashi, Nobuyuki (2000), "The Emergence of Generalized Exchange," American Journal of Sociology, 104 (4), 1105-34.

Terdman, Moshe, and Reuven Paz (2007), "Radical Islamist Attitude Towards HIV/AIDS-From Denial and Conspiracy Theories to the War on the Condoms," Prism Paper on Islamist Social Affairs, 2 (5), 1-20.

Terzis, Gillian (2011), "Indonesia's Looming AIDS Crisis," The Diplomat (February 3), http://thediplomat.com/2011/02/indonesiaslooming-aids-crisis/.

Thomas, Mark H. (2000). "Abstinence-Based Programs for Prevention of Adolescent Pregnancies: A Review," Journal of Adolescent Health, 26 (1), 5-17.

Umashankar, Nita, and Raji Srinivasan (2013), "Designing Social Interventions to Improve Newcomer Adjustment: Insights from the Indian Sex Worker Community," Journal of Public Policy \& Marketing, 32 (Fall), 271-85.

UNAIDS (2002), “Sex Work and HIV/AIDS," UNAIDS Technical Update, http://data.unaids.org/publications/IRC-pub02/jc705sexwork-tu_en.pdf.

UNAIDS (2010), "UNAIDS Report on the Global AIDS Epidemic: 2010," http://www.unaids.org/globalreport/Global_report.htm.

UNAIDS (2013), “The Gap Report,” http://www.unaids.org/sites/default/ files/en/media/unaids/contentassets/documents/unaidspublication/ 2014/UNAIDS_Gap_report_en.pdf. 
UNESCO (2010), "Education Sector Response to HIV, Drugs, and Sexuality in Indonesia," http://unesdoc.unesco.org/images/0018/ 001888/188887e.pdf.

USAID (2010), “Indonesia: Health,” https://www.usaid.gov/indonesia/ health.

Viswanathan, Madhubalan, José Antonio Rosa, and Julie A. Ruth (2010), "Exchanges in Marketing Systems: The Case of Subsistence Consumer-Merchants in Chennai, India," Journal of Marketing, 74 (May), 1-17.

Viswanathan, Madhubalan, Anju Seth, Roland Gau, and Avinish Chaturvedi (2009), "Ingraining Product-Relevant Social Good into Business Processes in Subsistence Marketplaces: The Sustainable Market Orientation," Journal of Macromarketing, 29 (4), 406-25.

Viswanathan, Madhubalan, Srinivas Sridharan, Robin Ritchie, Srinivas Venugopal, and Kiju Jung (2012), "Marketing Interactions in Subsistence Marketplaces: A Bottom-Up Approach to Designing Public Policy," Journal of Public Policy \& Marketing, 31 (Fall), 159-77.

Wang, Chih-Chien, Shao-Kang Lo, and Wenchang Fang (2008), "Extending the Technology Acceptance Model to Mobile Telecommunication Innovation: The Existence of Network Externalities," Journal of Consumer Behaviour, 7 (2), 101-10.

Wariki, Windy, Erika Ota, Narumi Hori, Rintaro Mori, and Kenji Shibuya (2010), "Behavioral Interventions to Reduce the Transmission of HIV Infection Among Sex Workers and Their
Clients in Low-Income and Middle-Income Countries," Cochrane Database of Systematic Reviews, 10, DOI: 10.1002/14651858. CD005272.pub2.

Warwick, Donald (1986), “The Indonesian Family Planning Program: Government Influence and Client Choice," Population and Development Review, 12 (3), 453-90.

Wee, S., M.E. Barrett, W.M. Lian, T. Jayabaskar, and K.W.R. Chan (2004), "Determinants of Inconsistent Condom Use with Female Sex Workers Among Men Attending the STD Clinic in Singapore," Sexually Transmitted Infections, 80 (4), 310-14.

Wolffers, Ivan (1999), "Pacar and Tamu: Indonesian Women Sex Workers' Relationships with Men," Culture, Health \& Sexuality, 1 (1), 39-53.

World Bank (2013), "Indonesia: Country at a Glance," http://www. worldbank.org/en/country/indonesia.

World Health Organization (2001), "HIV/AIDS in Asia and the Pacific Region," http://www.hivpolicy.org/Library/HPP000524. pdf.

World Health Organization (2013), "Global Health Observatory (GHO) Data," (accessed October 27, 2013), http://www.who.int/ gho/hiv/en/.

Worth, Dooley (1989), "Sexual Decision-Making and AIDS: Why Condom Promotion Among Vulnerable Women Is Likely to Fail," Studies in Family Planning, 20 (6), 297-307. 